\section{Antituberculosis drug-induced hepatotoxicity in children}

\author{
Peter R. Donald \\ Department of Paediatrics and Child \\ Health, Faculty of Health Sciences, \\ University of Stellenbosch and Tygerberg \\ Children's Hospital, Tygerberg, South \\ Africa
}

\section{Abstract}

Recent increases in the dosages of the essential antituberculosis agents isoniazid (INH), rifampicin (RMP), pyrazinamide (PZA) for use in children recommended by World Health Organization have raised concerns regarding the risk of hepatotoxicity. Published data relating to the incidence and pathogenesis of antituberculosis drug-induced hepatotoxicity (ADIH), particularly in children, is reviewed. Amongst 12,708 children receiving chemoprophylaxis, mainly with INH, but also other combinations of INH, RMP and PZA only 1 case $(0.06 \%)$ of jaundice was recorded and abnormal liver functions documented in $\mathbf{1 1 0}$ (8\%) of the 1225 children studied. Excluding tuberculous meningitis (TBM) 8984 were children treated for tuberculosis disease and jaundice documented in $75(0.83 \%)$ and abnormal liver function tests in 380 (9.9\%) of the 3855 children evaluated. Amongst 717 children treated for TBM, however, jaundice occurred in $72(10.8 \%)$ and abnormal LFT were recorded in 174 (52.9\%) of those studied. Case reports document the occurrence of ADIH in at least 63 children. Signs and symptoms of ADIH were frequently ignored in the recorded cases. ADIH can occur in children at any age or at any dosage of INH, RMP or PZA, but the incidence of.ADIH is is considerably lower in children than in adults. Children with disseminated forms of disease are at greater risk of ADIH. The use of the higher dosages of INH, RMP and PZA recently recommended by WHO is unlikely to result in a greater risk of ADIH in children.

\section{Introduction}

All pharmacological interventions balance efficacy and toxicity; there are few efficacious agents that do not have some toxicity risk. In the case of antituberculosis agents the major risk is hepatotoxicity and three agents identified by World Health Organization (WHO) as essential, isoniazid (INH), rifampicin (RMP) and pyrazinamide (PZA), carry such a risk. In view of recent recommendations for increased dosages of INH (5-15 mg/kg), RMP (10-20 $\mathrm{mg} / \mathrm{kg})$ and PZA (30-40 mg/kg) for children, ${ }^{1}$ this paper reviews knowledge of antituberculosis drug induced hepatotoxicity (ADIH) occurring amongst children. The role of the essential drugs INH, RMP and PZA implicated in $\mathrm{ADIH}$ is considered alone and in concert and factors that might influence ADIH in adults and children are discussed and literature relating to ADIH in children is reviewed and summarized.

\section{Materials and Methods}

A PubMed search used keywords hepatotoxicity, hepatitis, liver injury, antituberculosis treatment, chemoprophylaxis, chemotherapy, isoniazid, rifampin and rifampicin, pyrazinamide, childhood, children and paediatric. All papers published from 1944 up to December 2009 referring to children in the title or published in paediatric journals were reviewed. A personal collection of childhood tuberculosis literature was also scanned, particularly for earlier literature, and bibliographies of identified papers searched for additional references. Papers quantifying the occurrence of ADIH in children in any manner are included; this might mean, in some instances, the regular determination of serum transaminases and bilirubin or may refer only to the documentation of jaundice. Papers relating primarily to hepatotoxicity in adults have also been reviewed, particularly regarding the principles underlying hepatotoxicity. Papers in English, German, French, Italian and Spanish were included. Unless otherwise stated drugs were administered daily and dosages are given as $\mathrm{mg} / \mathrm{kg}$ implying that this is the daily dosage. The terms hepatotoxicity, hepatitis, liver damage and liver injury are used interchangeably in the literature, but for purposes of this review the term $\mathrm{ADIH}$ has been adopted and indicates any significant deviation from normal in liver function tests (LFT) or clinical signs that indicate liver dysfunction in the presence of antituberculosis treatment. Importance is placed on the identification of jaundice as an indisputable clinical sign of serious hepatic pathology. Data relating to ADIH under different circumstances was extracted from relevant papers and summarized under three headings: case reports, the use of INH, RMP and PZA in chemoprophylaxis and the use of the same agents in tuberculosis treatment. Account was taken of different drug dosages, especially that of INH, however classification as regards dosage is imprecise as many authors give a dosage range without indicating the mean or median dosage.

Several definitions of ADIH and approaches
Correspondence: Peter R. Donald, Paediatrics and Child Health, Stellenbosch University, P0 Box 19063, 7505 Tygerberg, South Africa.

Tel. +27.21 .9389592 - Fax: +27.21 .9389138$

E-mail address: mailto:prd@sun.ac.za

Key words: antituberculosis chemotherapy, hepatotoxicity, children, isoniazid, rifampicin, pyrazinamide.

Acknowledgements: this review was supported by a grant from WHO as part of the Better Medicines for Children project. The findings, interpretations and conclusions expressed in this paper are entirely those of the author and should not be attributed in any manner whatsoever to WHO.

Funding: PRD is supported by the National Research Foundation of South Africa.

Received for publication: 10 January 2011. Accepted for publication: 31 March 2011

This work is licensed under a Creative Commons Attribution NonCommercial 3.0 License (CC BYNC 3.0).

CC Copyright P.R. Donald, 2011

Licensee PAGEPress, Italy

Pediatric Reports 2011; 3:e16

doi:10.4081/pr.2011.e16

to possible $\mathrm{ADIH}$ appear in different texts including those of the American Thoracic Society (ATS), 2 the Council for International Organizations of Medical Sciences ${ }^{3}$ and the World Health Collaborating Centre for International Drug Monitoring. 4 These definitions have not been applied to papers reviewed, but the opinions of authors accepted as to what constituted ADIH. Each laboratory has its own normal values, these are seldom provided and there is little uniformity as to the definition of ADIH.

\section{Results}

Before any discussion of ADIH it is relevant to note that liver biopsy studies and autopsies reveal that a significant proportion of adults, before and after antituberculosis treatment commencement, have hepatic abnormalities including granulomata, histiocytic nodules and non-specific reactive hepatitis. ${ }^{5-8}$ The role these abnormalities might play in the development of symptoms and signs of ADIH during chemotherapy must remain speculative. Similar studies in children have been reported. Needle biopsy of the liver in 120 children (age range $31 / 2$ months to 14 years), with different forms of primary tuberculosis, produced histological evidence of bacillary dissemination in 
$17 \%$ of children. ${ }^{9}$ Among 71 children with uncomplicated primary tuberculosis, tubercles were noted in four and epithelioid nodules, consisting mainly of histiocytes, fibrocytes and lymphocytes, in eight cases; in 46 with more serious forms of disease, tubercles were seen in two children and histiocytic nodules in a further three. Similar results have been described by others. ${ }^{10,11}$

It should also be noted that LFT performed before the start of treatment or chemoprophylaxis may be abnormal in a significant proportion of adults and children; this is particulary likely with more severe disease. ${ }^{12-16} \mathrm{~A}$ recent official statement of the ATS also pointed out that individual transaminase values may vary as much as $45 \%$ during a single day or $10-30 \%$ on successive days. ${ }^{2}$

INH was introduced in 195217,18 and brought about an unprecendented rapid improvement in tuberculosis patients. Following its introduction for chemoprophylaxis, studies enrolling several thousands of participants were undertaken. ${ }^{19}$ This enthusiasm was dampened when hepatitis was reported in 19 individuals from Baltimore, USA, receiving prophylactic INH; jaundice developed in 13 and 2 died. ${ }^{20}$ It was later noted that Baltimore City experienced a simultaneous increase in liver cirrhosis deaths during this period, creating an excessively negative picture of the hepatotoxic propensity of INH. ${ }^{21}$ None the less these events led to a reassessment of the hepatotoxicity of INH and questioned the wisdom of INH chemoprophylaxis. ${ }^{22}$ It was soon apparent that in any group receiving INH for tuberculosis disease management, or chemoprophylaxis, a significant proportion developed signs and symptoms of ADIH.23-27 With hindsight early INH animal studies did demonstrate liver damage $^{28}$ and early case reports documented liver damage and jaundice associated with INH use (and overdosage);29-34 studies of series of patients receiving INH revealed increases in AST, ALT and disorders of other LFT. 35,36 Rereading documentation of early chemoprophylaxis studies also reveals cases of jaundice, the significance of which was not appreciated. 37

When INH hepatotoxicity was recognized it was already known that exposure to INH and its metabolites varied; there were probably three N-acetyltransferase 2 (NAT2) phenotypes, rapid, intermediate and slow acetylators of INH and there was great interest in the NAT2 phenotype in relation to ADIH. With definitive genotyping it is now indisputable that SS acetylators of INH are more likely to experience a rise in serum hepatic transaminases than rapid acetylators. ${ }^{38-41}$ Whether this translates into susceptibility to overt hepatotoxicity with all the manifestations of jaundice and liver failure is less obvious, although some investigators have identified slow acetylators as also being more susceptible to severe hepatotoxicity. ${ }^{42}$ By contrast the incidence of hepatotoxicity with jaundice in a series of clinical trials in Chennai, India, over a 20 year period was $1.9 \%$ amongst 1757 patients phenotyped as slow INH acetylators and 1.2\% amongst 1238 rapid acetylators; the difference was not significant. 43 Similarly in a randomized, doubleblind, placebo-controlled INH chemoprophylaxis trial 20838 individuals received INH and 6991 placebo. ${ }^{26}$ Ninety five cases of hepatitis occurred in the INH group, but only 7 in the placebo group; the difference was highly significant; furthermore 75 of the INH group became jaundiced, but only 5 in the placebo group. The individuals who developed ADIH were phenotyped as regards their NAT2 status and the distribution of rapid and slow acetylators was 50:50 which was that expected in the Middle European population evaluated.

Following the introduction of INH there was, initially, little awareness of possible ADIH complicating antituberculosis chemotherapy in children. Early descriptions of INH therapy in children by experienced clinicians also record dosages of INH, calculated as $\mathrm{mg} / \mathrm{kg}$ body weight varying from $10-15 \mathrm{mg} / \mathrm{kg}$ body weight ${ }^{44}$ to $20 \mathrm{mg} / \mathrm{kg}$ and higher $45-47$ and there is frequent comment that children do not experience undue toxicity. Similarly reports of INH chemotherapy trials during which children received INH in dosages of 5 or $10 \mathrm{mg} / \mathrm{kg}$ made little comment regarding possible ADIH. ${ }^{48-50}$ With the introduction of RMP and PZA, also potentially hepatotoxic agents, much greater concern emerged regarding ADIH in children.

The role of RMP in ADIH is still subject to considerable discussion. In guinea pigs and mice no hepatic lesions were demonstrable following RMP administration. ${ }^{51}$ In earlier experiments with rats RMP alone caused no hepatic damage, however the addition of INH caused major histological lesions in the liver. 52 Several adult studies compared experience with RMP combined with INH and with EMB. Amongst pulmonary tuberculosis patients treated for the first time with INH and RMP some disturbance of LFT was noted amongst 13 (35\%) of 37; amongst 72 retreatment patients given RMP and EMB only 6 (8\%) developed a transient rise in transaminase values and one a rise in serum bilirubin. ${ }^{53}$ Later the same group described 110 previously untreated pulmonary tuberculosis patients receiving INH and RMP and a transient rise in transaminase values occurred in 21 (23\%) and a rise in serum bilirubin in 8 (11\%). ${ }^{54}$ An extensive review of RMP published in 1971 summarized experience with RMP hepatotoxicity following monotherapy and as part of multidrug therapy; amongst 1366 individuals receiving RMP montherapy $5(0.37 \%)$ became jaundiced and 1 $(0.07 \%)$ developed biochemical abnormalities; 55 amongst 4280 patients treated with RMP and other drugs, including INH, 80 (1.87\%) developed jaundice and another $27(0.6 \%)$ other biochemical abnormalities. The case report of Askgaard et al. also provides an instructive window on the interplay of INH and RMP in ADIH. 56 Precisely why RMP should have such a deleterious influence on INH hepatotoxicity is uncertain; RMP may induce INH hydrolase and thus increase the amount of INH directly converted to isonicotinic acid and hydrazine; slow acetylators of INH might then be more exposed to hydrazine and hepatotoxicity. 57

In 1954 McDermott et al enthusiasticaly described experience with INH and PZA combined in daily dosages of $5 \mathrm{mg} / \mathrm{kg}$ and $50 \mathrm{mg} / \mathrm{kg}$ respectively given twice daily. 58 of 53 patients with 3 month and 6 month bacteriological results $92 \%$ remained culture negative; unfortunately hepatitis occurred in six (10\%) patients, four became jaundiced and one died of fulminant hepatitis. The first four cases of hepatitis occurred during the 5th month of treatment and the PZA treatment duration was shortened to 90 days, but the fatal hepatitis case occurred at 55 days treatment and PZA use was stopped altogether. A later study by the same group gave PZA in a lower dosage of 20$30 \mathrm{mg} / \mathrm{kg}$, however efficacy was also lower and the risk of hepatotoxicity was not eliminated. 59 However when PZA was studied at daily dosages of $30-40 \mathrm{mg} / \mathrm{kg}$ together with other drugs in British Medical Research Council (MRC) trials the incidence of ADIH was low: 3 $(0.2 \%)$ of 1845 patients in East and Central Africa, $13(0.6 \%)$ of 2219 patients in Hong Kong and $11(2.8 \%)$ of 397 patients in Singapore. ${ }^{60}$ The demonstration of the unique sterilizing capacity of RMP and PZA revolutionized antituberculosis regimens and introduced six months short-course chemotherapy. 61 The identification of the first two months of therapy as critical for the action of PZA in combination with the powerful sterilizing activity of RMP led to the evaluation of this combination for two month chemoprophylaxis regimens. An early study of two months RMP and PZA, however, found a significant incidence of adverse events that contributed to non-compliance, ${ }^{62}$ but larger studies in HIV-infected patients of the combination of RMP and PZA given daily ${ }^{63}$ or twice weekly64,65 in comparison to INH also given daily or twice weekly, suggested that the RMP/PZA combination was both safe and efficacious and it was recommended by the ATS. 66

Unfortunately further studies found the combination of RMP and PZA to be associated with an unacceptable incidence of $\mathrm{ADIH} ; 67-71$ and Lee et al. emphasized the need for careful monitoring of patients receiving RMP and PZA.72 Some studies also included a small number of children. Kandula et al. managed 10 children with two months RMP/PZA; one child aged 15 years developed severe ADIH. ${ }^{73}$ 
Concerns regarding chemoprophylaxis with RMP and PZA were confirmed in an extensive programme survey in the USA of RMP/PZA usage for latent tuberculosis. ${ }^{74}$ The incidence of ALT values higher than X5 normal and ADIH per 1,000 RMP/PZA initiations was 25.6 (95\% CI 22.3-29.3) and 18.7 (CI 15.9-21.9) respectively; there were seven fatalities (rate 0.9) and 23 hospitalizations (rate 2.8 per 1,000 RMP/PZA initiations). Hong Kong researchers also presented a cohort and nested case study of pulmonary tuberculosis management with combinations of INH, RMP and PZA; adding PZA to INH and RMP during the continuation phase of therapy increased the ADIH risk appreciably. 75 None the less some studies of adults $^{76}$ and children 77 have reported acceptable levels of hepatotoxicity associated with the chemoprophylactic use of 2 months of RMP and PZA and emphasized the advantages of improved compliance with shorter regimens.

Le Bourgeois et al. studied PZA in 42 children receiving a mean dosage of $23.3 \mathrm{mg} / \mathrm{kg}$ (range $20-37 \mathrm{mg} / \mathrm{kg}$ ) with INH and RMP at recommended dosages. ${ }^{78}$ AST and ALT values at 1 month and at treatment conclusion rose to more than X3 normal in only 2 children (5\%); treatment was not interrupted and the increased values normalized. Sánchez-Albisua et al. described the use of PZA $(20-25 \mathrm{mg} / \mathrm{kg})$, INH (10 mg/kg) and RMP (15 mg/kg) in a cohort of 114 children. Eleven children (19.6\%) with normal ALT values before treatment experienced an increase in values; however the highest value was $193 \mathrm{U} / \mathrm{L}$ and only four children had values $>65 \mathrm{U} / \mathrm{L} .79$ In a retrospective study from Japan 99 children aged 0-16 years treated for tuberculosis were assessed. 80 In 22 children (22.2\%) AST or ALT values were increased, but $<$ X5, the upper limit of normal; severe ADIH, (an elevation of AST or ALT values to more than X5 normal in those with normal values pre-treatment), occurred in 8 (8.1\%) children, and young age and PZA use were associated with ADIH. It should be noted that only 12 children received PZA in this study and that 4 were amongst those developing ADIH and that 4 of these 8 children had severe disease in the form of tuberculous meningitis. In univariate analysis disease severity was an ADIH risk factor, but not in multivariate analysis. A single case report also suggested that RMP and PZA combined might have contributed to serious ADIH in a 10 year old child. 81

\section{The influence of infectious hepatitis}

Viral infectious hepatitis, is common in developing countries, may predispose to $\mathrm{ADIH}$, and be confused with ADIH and thus have a significant influence on the interpretation of results of many studies. ${ }^{82-85}$ The ATS, in a review of ADIH, concluded that it was not possible to reach firm conclusions about the role of hepatitis $\mathrm{B}$ virus infection in precipitating or exacerbating ADIH. ${ }^{2}$ HIV-infection and its treatment add another element to this problem. In a cohort of African patients receiving antiretroviral therapy, although there was a low incidence of hepatotoxicity, carriage of $\mathrm{HBsAg}$ and antituberculosis therapy increased the risk of hepatotoxicity significantly. 86 Türktas et al. studied infectious forms of hepatitis amongst 705 adult Turkish tuberculosis patients. ${ }^{87}$ Serologic markers (IgM) for viral hepatitis were studied amongst 57 (8.1\%) patients who developed acute ADIH with jaundice during treatment with INH and RMP and confirmed hepatitis B in 6 (10.5\%) patients, while 4 (7\%) were hepatitis C positive. Four patients (7\%) were HBsAg-positive, and this was within the range reported for Turkey. The authors comment that the reported incidence of $\mathrm{ADIH}$ is often higher in developing countries, but that not all cases of hepatitis during antituberculosis treatment may be due to ADIH. Similar conclusions were drawn by other researchers ${ }^{88}$ and three recent studies from India have also identified viral hepatitis as a common complicating factor in $10-15 \%$ of patients presenting with apparent ADIH.89-91

With regard to children early reports of possible INH ADIH often carried suggestions that infectious hepatitis, or other intercurrent infections, might mimick INH ADIH or increase susceptibility to ADIH. 12,92-95

Dieu, after describing a high jaundice incidence amongst his patients discusses the subject at length and, in the absence of epidemiological evidence of an infectious hepatitis outbreak in the relevant ward, considered this an unlikely explanation for the high incidence of severe ADIH encountered. ${ }^{93}$ Several reports of ADIH also document infectious forms of hepatitis in children presenting with jaundice while receiving antituberculosis treatment.16,96,97 Such forms of hepatitis are particularly likely in children hospitalized with more serious forms of tuberculosis for a prolonged period. Kumar et al. studied serological markers for hepatitis viruses amongst 40 children who developed ADIH characterized by jaundice and raised serum ALT and bilirubin during INH and RMP therapy, both in dosages of $10-20 \mathrm{mg} / \mathrm{kg}$ body weight daily. ${ }^{98}$ Hepatitis A and B were shown to be associated with apparent ADIH in $7.5 \%$ and $35 \%$ of children respectively. Epidemiological evidence suggested that non$A$ and non-B viruses could have been responsible for hepatitis amongst at least some of the remaining 23 children. The authors conclude that the high ADIH incidence reported from some developing countries may be due to infectious forms of hepatitis; the risks for infection being exacerbated by poor hygiene and the need for parenteral therapy in severely ill children. As the fatality rate was $20 \%$ amongst the 40 children described the problem has serious implications. Studies by Dieu, Burghard, Ramachandran, Rugamini \& Mehta, Tsagaropoulou -Stinga et al.99-103 all reported very high incidences of jaundice associated with high dosages of INH and RMP, but others using equally high INH and RMP dosages have not experienced this level of serious liver disease.16,104,105 Part of these reported differences may well be due to the occurrence of undetected infectious hepatitis.

\section{Antituberculosis drug-induced hepatotoxicity in children}

There is now no doubt that children experience ADIH and 26 papers summarized in Table 1 give details of possible ADIH in 33 children. While evidence supporting ADIH in some cases might be regarded as flimsy, there are several cases, where rechallenge with the relevant agent confirmed the etiology. The median age of children was five years and eight (24\%) received an INH dosage of $20 \mathrm{mg} / \mathrm{kg}$ or more, five (15\%) a dosage of $15 \mathrm{mg} / \mathrm{kg}$ and the remaining 19 (58\%) $10 \mathrm{mg} / \mathrm{kg}$ or less. A recent report describes a further 20 children (0-17 years) who experienced fulminating INH-related hepatic failure; 129 in this last report the median age of the children was 10.5 years and all the dosages of INH were $<12 \mathrm{mg} / \mathrm{kg}$ ( 6 not available). An earlier paper reviewed possible INH related deaths in the USA between 19651989 , and identified 14 cases $<20$ years of age, but these probably also include older adolescents and may well include cases described in this present review. 130

It must be emphasized that a common theme in these reports is the frequency with which INH treatment, either alone or accompanied by RMP and PZA, was continued in the face of symptoms indicating possible ADIH.

\section{ADIH in children receiving chemoprophylaxis}

Eighteen papers record INH chemoprophyalxis in children and comment on adverse events. Seven give details of 2149 children receiving an INH dosage of 4-6 $\mathrm{mg} / \mathrm{kg}$; serum transaminase values were determined regularly in 461children and 56 (12.1\%) had increased values; treatment was discontinued in five (0.23\%), no child developed jaundice. ${ }^{77,131-136}$ Four studies enrolled 1451 children who received an INH dosage of $10 \mathrm{mg} / \mathrm{kg} ;{ }^{121,137-139}$ of 369 whose LFT were routinely determined 


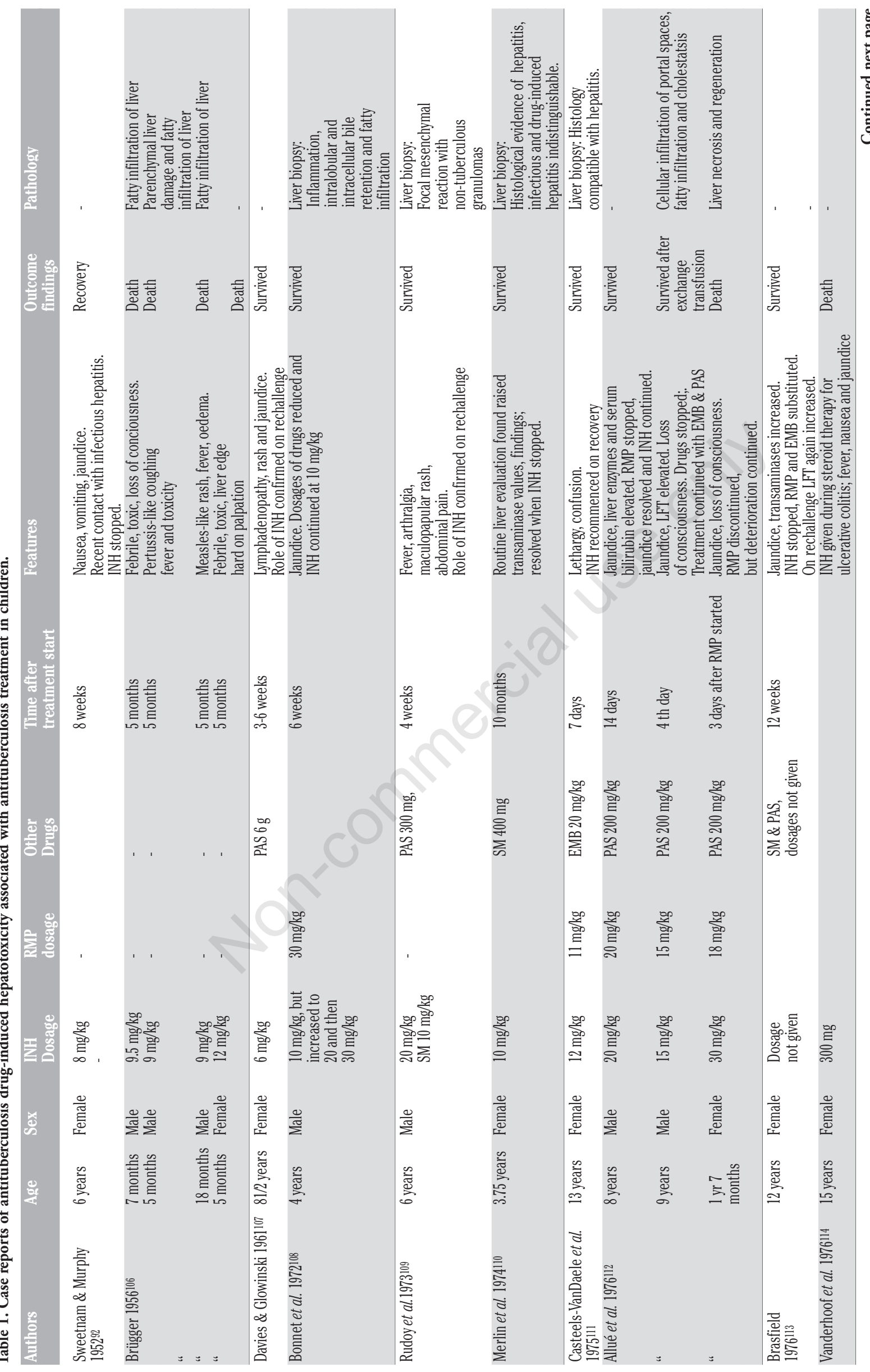



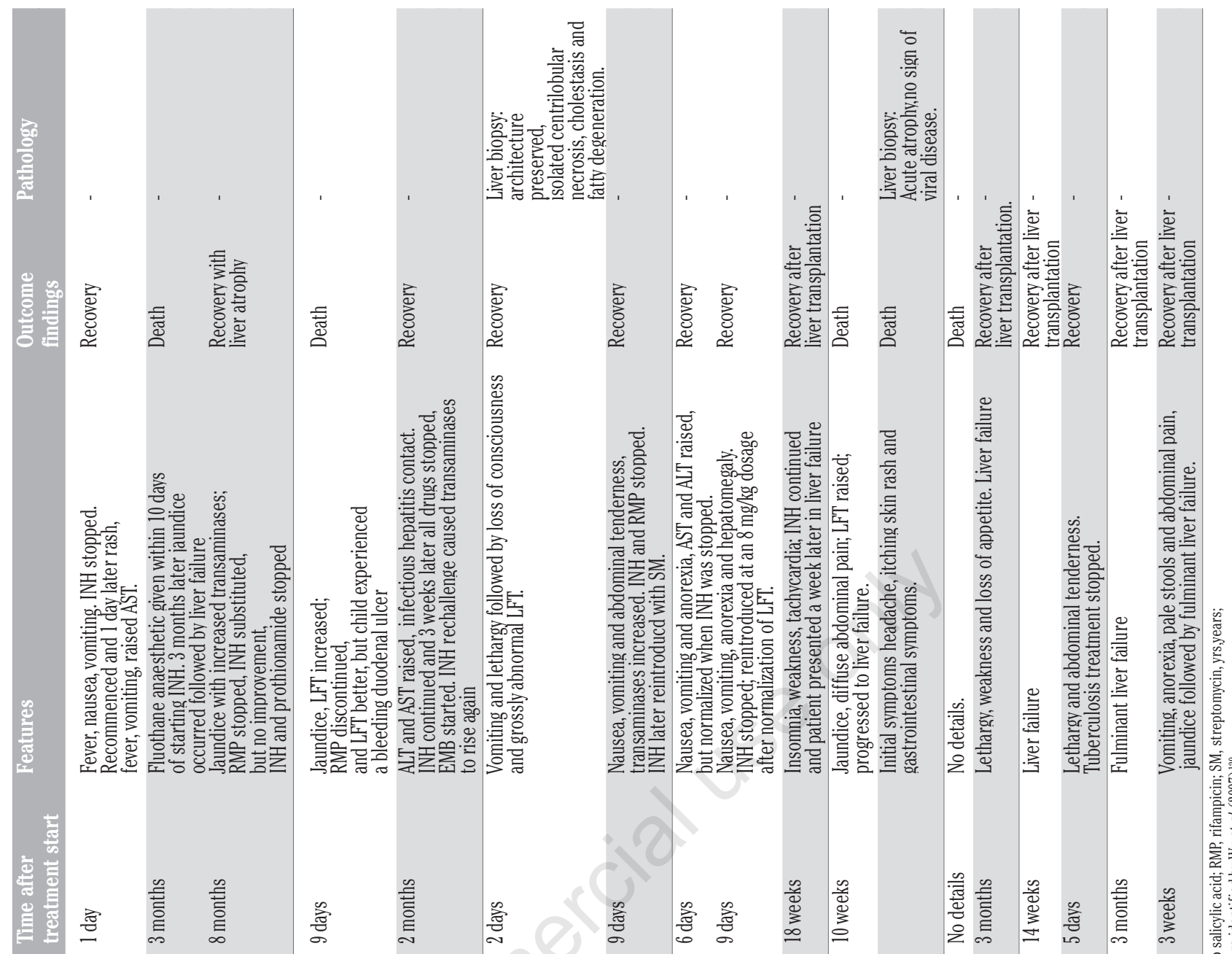

㺃产

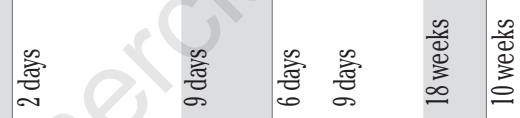

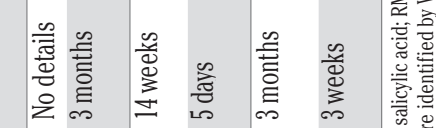
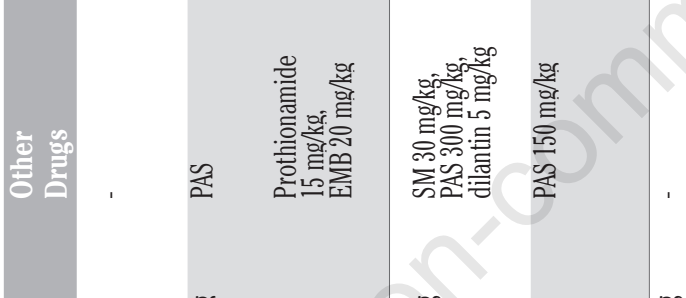

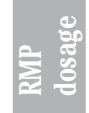

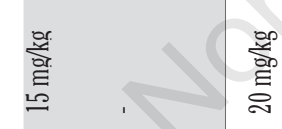

$=\stackrel{8}{8}$
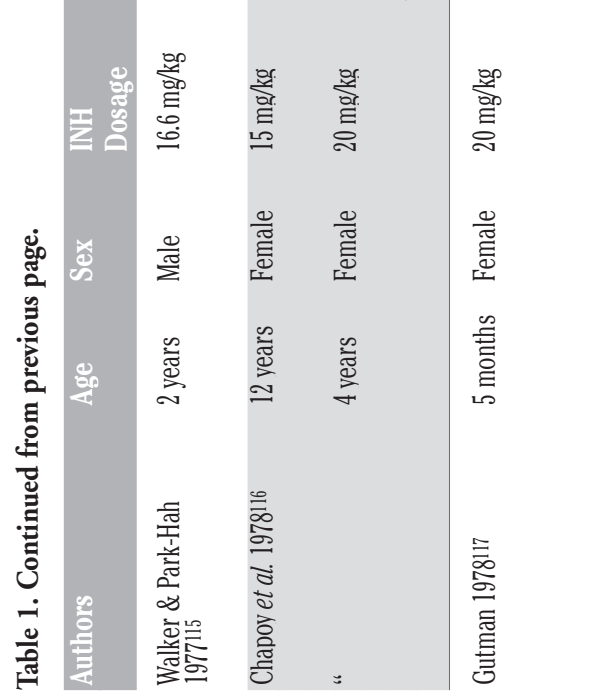

$\frac{\sqrt{2}}{\frac{\pi}{2}}$
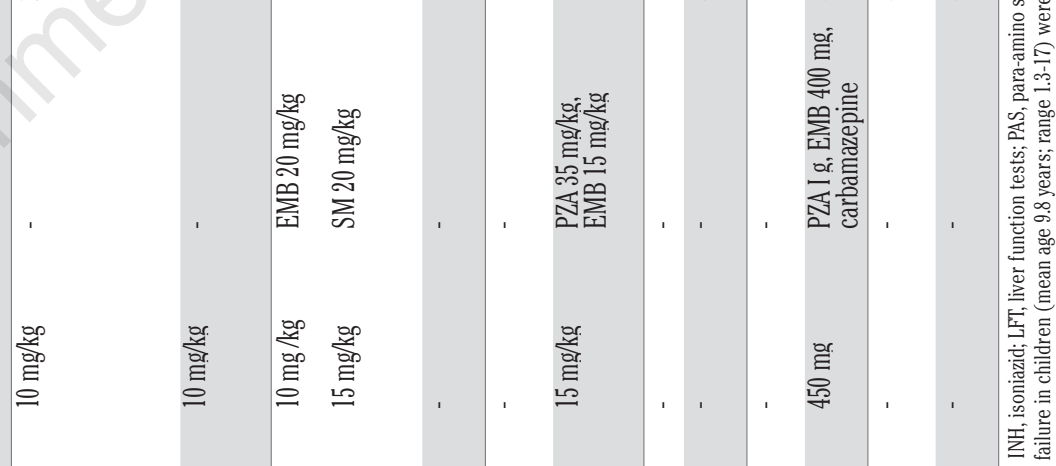

, 竞

商 商 竞

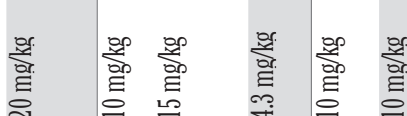

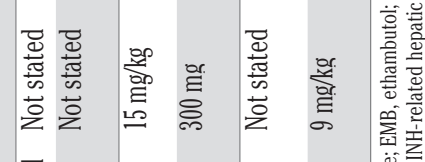

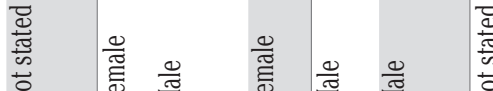

焉

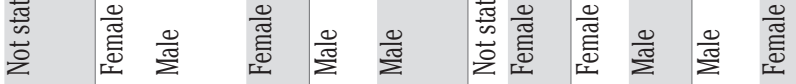

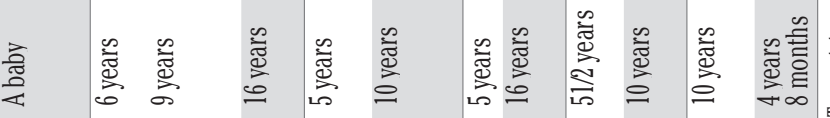

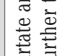
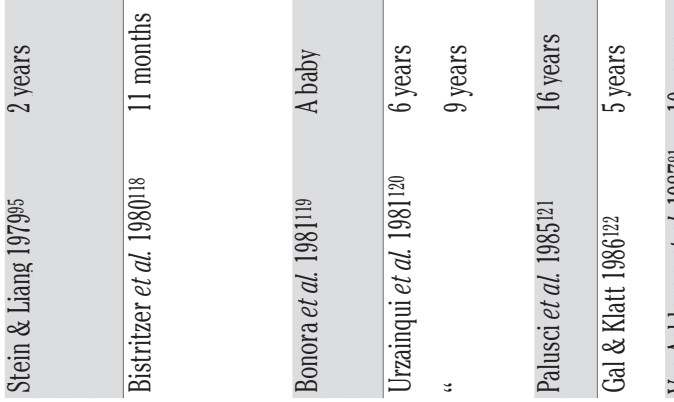

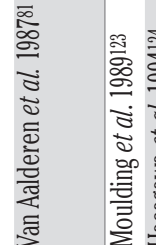

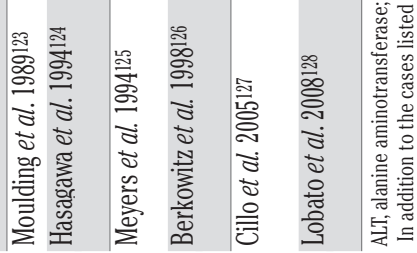


$25(6.8 \%)$ had increased values. Jaundice developed in 1 child (0.07\%), symptoms or signs indicative of $\mathrm{ADIH}$ were experienced by 64 (4.4\%), but treatment was stopped in only 2 (0.14\%).

An INH dosage of $10-20 \mathrm{mg} / \mathrm{kg}$ was administered in 7 studies enrolling 7528 children. ${ }^{140-}$ 146 No child became jaundiced and only four $(0.05 \%)$ had symptoms or signs of ADIH. Details of LFT were provided by Rapp et al. and 17 (14.7\%) of 116 children had abnormal values. ${ }^{142}$ In the study of Byrd et al. details are not provided but LFT were determined monthly and no child had values more than X5 normal. ${ }^{143}$ Two papers record RMP use alone in chemoprophylaxis for 182 children and adolescents. ${ }^{77,147}$ Both studies recorded liver functions and found values above normal in 11 (6.04\%); all were asymptomatic, but RMP was stopped in one adolescent with ALT values $>\mathrm{X} 2$ normal. The study of Lardazibal et al. recorded no cases of hepatitis amongst approximately 166 individuals aged 1-24 years receiving four months RMP for chemoprophylaxis, but the precise ages of participants are not given.148 For comparison the use of RMP alone for chemoprophylaxis amongst adults is recorded in 3 studies; ${ }^{149-151}$ very low rates of ADIH were also found. In the study of the Hong Kong Chest Service no difference was found in mean LFT values of patients receiving RMP or placebo; ${ }^{149}$ Polesky et al. recorded no symptomatic ADIH 150 and in the study of Menzies et al. no patients experienced a significant rise in transaminase values. ${ }^{151}$ Further evidence that RMP is responsible for significantly less hepatotoxicity than INH is provided by Menzies et al. (2008). ${ }^{152}$ Of 422 individuals receiving INH chemoprophylaxis 16 (3.8\%) developed grade $3-4$ hepatitis compared to $3(0.7 \%)$ of 418 receiving $\mathrm{RMP}(\mathrm{P}=0.003)$.

In four papers the use of INH and RMP, both at a $10 \mathrm{mg} / \mathrm{kg}$ dosage, in 1301 children $0-15$ years is described;139,153-155 in the study of Wales et al. the RMP dosage was $10-15 \mathrm{mg} / \mathrm{kg}$. In 13 (1\%) children symptoms of nausea, vomiting or epigastric pain occurred, but in no case was treatment interrupted. 153 Liver function tests were not routine in any of the studies, but in the study of Wales et al. a transient rise in transaminase values occurred in eight children. The authors also record the use of INH and RMP chemoprophylaxis in another 46 children during a school outbreak of tuberculosis without adverse events.

Three papers describe two months RMP (10 $\mathrm{mg} / \mathrm{kg}$ ) and PZA (15-30 mg/kg) for chemoprophylaxis in 97 children.73,77,134 Magdorf et al. evaluated liver functions pre-treatment and at one and two months after starting treatment; although mean values increased no children had abnormal values.77 One of 11 children aged 15 years in the study of Kandula et al. developed an asymptomatic increase in ALT to
X5 normal values and treatment was stopped. ${ }^{73}$ The liver enzymes were studied fortnightly in 23 adults, but this was not always possible in the children, although they were seen and examined fortnightly; amongst the adults 4 (17.3\%) developed ADIH. Tortajada et al. studied 56 children $0-19$ years of age and 213 adults and liver enzymes were determined at two, four, six and eight weeks after starting treatment.134 No child had grade 3 or more ADIH and none had any signs or symptoms of ADIH. Amongst 213 adults enrolled ADIH occurred in $20(9.4 \%)$. The numbers of children enrolled in these last three groups of studies are relatively small, but provide little indication of any serious risk of ADIH in comparison to experience in adults. ${ }^{2}$ Table 2 is a condensed summary of all studies documenting ADIH associated with chemoprophylaxis. Abnormal LFT were recorded in $110(9.0 \%)$ of 1225 children evaluated, jaundice occurred in one child $(0,01 \%)$ of the 12,708 studied and treatment was discontinued in eight $(0.06 \%)$ children.

\section{Hepatotoxicity of Antituberculosis agents in children treated for tuberculosis}

Despite initial complacency regarding hepatotoxicity the introduction of RMP and later PZA into routine treatment, together with reports of hepatotoxicity in adults, created circumspection in managing children; from approximately 1970 reports of treatment of children with tuberculosis disease frequently refer to LFT evaluation or the occurrence of jaundice in children receiving INH, RMP and PZA. In this review 69 papers are referenced giving details of children treated for tuberculosis that evaluate or comment on ADIH.

The majority of papers document daily therapy, but partial or total intermittent therapy was described in several papers.97,156-163 In general, intermittent regimens were associated with less hepatotoxicity, but were also frequently used for less serious forms of tuberculosis.

Two papers report early studies in which INH monotherapy was used to manage tuberculosis disease in 218 children; ${ }^{163,164}$ in only one were liver functions studied and four of 50 (8\%) children had increased LFT values. ${ }^{164}$ One child $(0.46 \%)$ developed jaundice.

Thirteen studies recorded treatment of 3053 children with INH dosages of 10-20 mg/kg and drugs other than RMP.12,102,156,163,165-173 The additional drugs commonly used were SM, PAS and EMB and in one study PZA.172 Jaundice occurred in 12 children (0.39\%); serum transaminase values were routinely determined in 443 children and increased in 49
(11.1\%). There were several interesting observations. Mantero et al. phenotyped 54 children as rapid (22) or slow (32) INH acetylators; of 14 children developing increased AST levels only two $(9.1 \%)$ were rapid INH acetylators and $12(37.5 \%)$ slow, suggesting an influence of INH concentrations on ADIH.170 Jaundice occurred in 12 children and in nine this was associated with INH dosages of $\geq 20 \mathrm{mg} / \mathrm{kg}$ and in 1 case $\geq 15 \mathrm{mg} / \mathrm{kg}$; it is noteworthy that eight of 12 cases of jaundice were reported in one study. 169 Three papers give details of the management of children with INH $8-15 \mathrm{mg} / \mathrm{kg}$ and RMP. $99,174,175$ All 224 children entered in these studies had AST and ALT regularly evaluated and 32 (14.3\%) had increased values on at least one occasion. Two children (0.9\%) became jaundiced ${ }^{99}$ and three (1.3\%) experienced symptoms compatible with ADIH. The study of Dieu is frequently referrenced regarding the interaction of INH and RMP and the influence of increased INH dosages. ${ }^{99}$

Seven studies record details of 453 children receiving INH dosages of $10-20 \mathrm{mg} / \mathrm{kg}$ together with RMP, but no other agents. ${ }^{99,100,102 \text {, }}$ $156,158,169,176$ AST and ALT levels were not reported in 3 studies and amongst the remaining 5 studies 413 children were evaluated and increased AST or ALT values found in 64 (15.5\%). Jaundice occurred in 52 children (11.5\%). The percentage of children with jaundice is high and strongly influenced by the studies of Dieu,99 Burghard et al., 100 Bassetti et al. 176 and Rugamini \& Mehta. ${ }^{102}$ However, whether or not infectious causes of hepatitis underlie some of these cases, it remains true that the incidence of jaundice was influenced by the INH dosage; the studies of Dieu, ${ }^{99}$ Burghard et al. ${ }^{100}$ and Rugamini \& Mehta 102 provide evidence that reducing the INH dosage to a maximum of $15 \mathrm{mg} / \mathrm{kg}$ has a considerable influence on susceptibility to severe ADIH.

Sixteen papers describe the findings in 2714 children receiving an INH dosage of approximately $10 \mathrm{mg} / \mathrm{kg}$ (range $5-14 \mathrm{mg} / \mathrm{kg}$ ), together with RMP and other agents. $13,78,80,94,157,161,177$ 186 In four studies LFT were not evaluated; amongst 1762 children regularly evaluated 141 (8.0\%) had increased transaminase levels and amongst the whole group jaundice was observed in three children $(0.11 \%)$. Symptoms or clinical signs of ADIH were observed in 35 children (1.3\%).

Nine studies enrolled 2332 children who received an INH of dosage $10-20 \mathrm{mg} / \mathrm{kg}$ together with RMP and other drugs. ${ }^{160,171,172,186-191}$ In two studies LFT were regularly evaluated in 1406 children;187,189 AST and /or ALT levels were increased in 139 (9.9\%). Jaundice occurred in five $(0.22 \%)$.

Fifteen papers described 717 children treated for TBM; in four 259 children received INH dosages of $10-15 \mathrm{mg} / \mathrm{kg} .12,101,192,193$ In only one study were LFT determined and these children 
Table 2. Antituberculosis drug-induced hepatotoxicity in children receiving chemoprophylaxis.

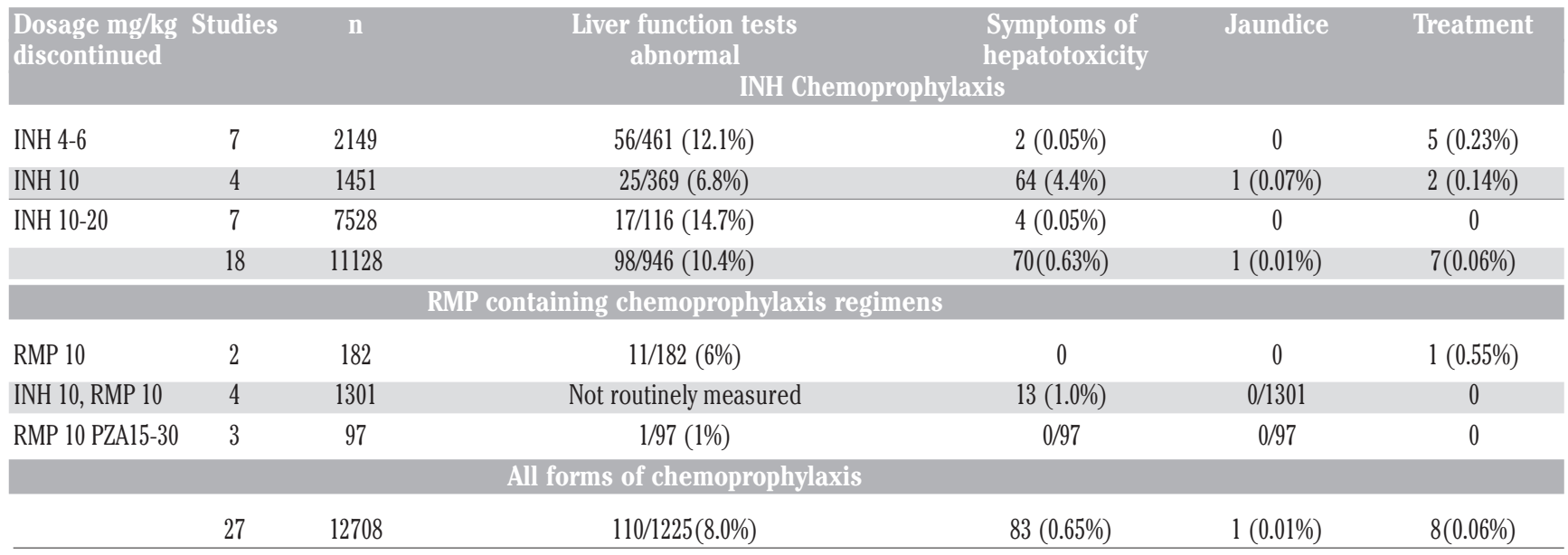

INH, isoniazid; PZA, pyrazinamide; RMP, rifampicin.

Table 3. Antituberculosis drug-induced hepatotoxicity in children treated for tuberculosis.

\begin{tabular}{|c|c|c|c|c|c|}
\hline Drugs & $\begin{array}{l}\text { INH Dosage } \\
\mathrm{mg} / \mathrm{kg}\end{array}$ & Studies & $\mathbf{N}$ & Liver function tests abnormal & $\begin{array}{l}\text { Symptoms or } \\
\text { signs of liver disease }\end{array}$ \\
\hline INH & $6-10$ & 2 & 218 & $(8.0 \%)$ & Jaundice in $1(0.46 \%)$ \\
\hline INH \& other agents & $<10-20$ & 13 & 3053 & $49 / 443 \quad(11.1 \%)$ & Jaundice $12 \quad(0.39 \%)$ \\
\hline INH \& RMP & 8-15 & 3 & 224 & $32 / 224 \quad(14.3 \%)$ & 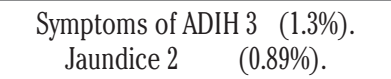 \\
\hline INH \& RMP & $10-20$ & 7 & 453 & $64 / 413 \quad(15.5 \%)$ & Jaundice $52 \quad(11.5 \%)$. \\
\hline INH \& RMP and other agents & $5-14$ & 16 & 2714 & $141 / 1762(8.0 \%)$ & $\begin{array}{cc}\text { Symptoms of ADIH } 35 \text { (1.3\%). } \\
\text { Jaundice } 3 & (0.11 \%)\end{array}$ \\
\hline INH \& RMP and other agents & $10-20$ & 50 & $\begin{array}{l}2322 \\
8984\end{array}$ & $\begin{array}{l}139 / 1406(9.8 \%) \\
380 / 3855(9.9 \%)\end{array}$ & $\begin{array}{cc}\text { Symptoms of ADIH } 6 & (0.26 \%) \text {. } \\
\text { Jaundice } 5 & (0.22 \%) \\
\text { Symptoms of ADIH } & 32(0.36 \%) \\
\text { Jaundice } 75 & (0.91 \%)\end{array}$ \\
\hline \multicolumn{6}{|c|}{ Tuberculous meningitis } \\
\hline INH, RMP and other agents & $10-15$ & 4 & 259 & Not routinely determined & $\begin{array}{l}\text { Other drugs substituted } 23 \text { (8.9\%). } \\
\text { Jaundice } 26 \quad(10.0 \%)\end{array}$ \\
\hline INH, RMP and other agents & $10-20$ & $\begin{array}{l}11 \\
15\end{array}$ & $\begin{array}{l}458 \\
717\end{array}$ & $\begin{array}{l}174 / 329(52.9 \%) \\
174 / 329(52.9 \%)\end{array}$ & $\begin{array}{c}\text { Jaundice } 46(10.0 \%) \\
\text { Jaundice } 72 / 717(10.04 \%)\end{array}$ \\
\hline
\end{tabular}

INH, isoniazid; RMP, rifampicin.

were probably treated with INH alone. ${ }^{12}$ Amongst these 14 eight (57\%) had increased LFT levels before treatment and at four weeks after treatment commencement four (29\%) still had increased values. The author implies that the only children with abnormal values were those with increased values pre-treatment. He also describes 9 of 21 children treated with INH who developed measles or varicella and in whom LFT increased by a factor of X4 to $\mathrm{X} 6$ normal values, but INH was continued without any deleterious effects.

Jaundice was reported in 26 children (10.04\%) and all 26 cases come from the studies of Ramachandran et al. ${ }^{101}$ and Parasarathy et al. ${ }^{192}$ In the study of Parasarathy et al. ADIH was almost entirely confined to patients (adults and children) receiving INH and
RMP.192 When ADIH did occur it was mainly in the intensive phase and was also more frequent in phenotypically slow acetylators of INH, implying that exposure to higher INH concentrations plays a role in $\mathrm{ADIH}$. When RMP was given intermittently the incidence of jaundice was also lower. The authors also point out that viral hepatitis is endemic in South India; both INH and RMP might contribute to exacerbating subclinical viral hepatitis and this effect could be more marked with higher drug dosages.

Eleven papers described 458 children treated for TBM with INH dosages ranging from 1520 mg/kg. 16,96,101,103-105,168,192,194,195,196 Again a very high proportion $(174 ; 52.9 \%)$ of 329 children in whom concentrations of transaminases were determined had increased values.
Table 4. Selected studies of adults with tuberculosis receiving INH and RMP recording an increase in transaminase values above normal

\begin{tabular}{lcc} 
Authors & n & $\begin{array}{c}\text { Increased } \\
\text { transaminase } \\
\text { values }\end{array}$ \\
Lees et al. 197153 & 105 & $37(35 \%)$ \\
Lal et al. 1972201 & 63 & $14(22 \%)$ \\
\hline Lees et al. 197254 & 110 & $21(23 \%)$ \\
Grönhagen-Riska 1978202 & 319 & $58(18 \%)$ \\
\hline Musch et al. 198242 & 86 & $30(34 \%)$ \\
Hwang et al. 199783 & 240 & $63(26 \%)$ \\
\hline Agal et al. 2005203 & 200 & $221(11 \%)$ \\
\hline & 1123 & $244(22 \%)$ \\
\hline
\end{tabular}


Jaundice was also reported in a high proportion, affecting 46 (10.04\%) and in the studies of Rahajoe et al.,168 Ramachandran,101 Tsagaropoulou-Stinga et al. ${ }^{103}$ and Parasarathy et al. 192 the proportion of children becoming jaundiced varied from $29 \%$ to $50 \%$; other studies using similar regimens with equally high drug dosages, although reporting a high proportion of children with increased transaminase values $16,96,104,105,194$ found a much lower incidence of jaundice or no cases of jaundice.

Table 3 summarizes ADIH amongst children treated for tuberculosis disease. Excluding TBM, 8984 children were treated for disease with jaundice reported in 75 ( $0.83 \%)$; LFT were evaluated in 3855 children and were abnormal in 380 (9.9\%). TBM treatment was recorded for 717 children and jaundice occurred in 72 (10.04\%) and abnormal LFT in 174 (52.9\%) of 329 children. The study of Diekoff was not included in the tabulation of LFT results due to the early methodologies used. ${ }^{12}$

\section{Discussion}

The most important finding of this review is that ADIH, however defined, occurs in children, but that the incidence is lower than in adults receiving comparable drug dosages and regimens. The contrast between children and adults is clearest in chemoprophylaxis studies enrolling children and adults in the same study. Amongst children approximately 10\%, receiving either INH alone or INH accompanied by RMP or RMP and PZA, experience a rise in serum transaminase values or (in older studies) an abnormality in LFT. Less than 1\% are recorded as having symptoms of $\mathrm{ADIH}$ and only 1 child amongst more than 12,000 receiving INH chemoprophylaxis is recorded as developing jaundice. Very similar results are found amongst much smaller numbers of children receiving RMP containing prophylactic regimens. As regards PZA only 97 children entered in 3 studies are recorded who received PZA with RMP for chemoprophylaxis, but the risk of ADIH does not appear serious.

Amongst children treated for tuberculosis disease a different picture emerges. Although a similar proportion of children (approximately $10 \%$ ) experience increased serum transaminase values, a considerably larger proportion presented with jaundice than amongst those managed for latent infection; this proportion varies from less than $1-50 \%$ in some studies of children treated for TBM. Several factors may be important in this regard.

Disease severity plays a role in the frequency of ADIH ${ }^{91,171}$ and underlying hepatic abnormalities present in both adults5-8 and children $^{9-11}$ before the start of treatment, especially in disseminated forms of tuberculosis, may be relevant in this regard; a large proportion of children will also have abnormal LFT before treatment. This is particularly likely in children with disseminated disease that might accompany TBM. The study of Dieckhoff 12 found no abnormal LFT amongst children with uncomplicated primary tuberculosis prior to treatment, but abnormal LFT amongst $57 \%$ of 14 children with TBM not complicated by miliary tuberculosis and $68 \%$ of 63 children with miliary tuberculosis without TBM.

In regimens including INH and drugs other than RMP there are indications that the INH dosage may play a role in ADIH: of 12 cases of jaundice reported following the use of INH with drugs other than RMP, 9 occurred in children receiving an INH dosage of $20 \mathrm{mg} / \mathrm{kg}$ or higher. ${ }^{102,168,169}$ With regard to children receiving only INH and RMP a number of authors commented on a reduced incidence of severe ADIH and jaundice, when the INH dosage was reduced to less than $15 \mathrm{mg} / \mathrm{kg}^{99-101,168,169,192,196}$ or less than $10 \mathrm{mg} / \mathrm{kg} .{ }^{102}$ Amongst the 3 studies giving details of 224 children treated with only INH and RMP and receiving an INH dosage of approximately $8-15 \mathrm{mg} / \mathrm{kg}$, only $2(0.9 \%)$ children became jaundiced ${ }^{99,174,175}$ compared to 52 (11.5\%) of 453 children receiving INH in dosages of $10-20 \mathrm{mg} / \mathrm{kg} .{ }^{99,100,102,156,158,169,176}$ Turning to those studies where INH and RMP were combined with other agents, often including PZA, jaundice occurred in only 2 $(0.07 \%)$ of 2714 children receiving RMP and INH in a dosage of approximately 10 $\mathrm{mg} / \mathrm{kg} 13,79,80,94,157,161,177-185$ and $5(0.21 \%)$ of 2413 children receiving an INH dosage of 10-20 $\mathrm{mg} / \mathrm{kg}$, which does not suggest an influence of INH dosage. ${ }^{171,172,186-191}$ There is also not a significant influence of dosage regarding those with increased serum transaminases; increased values were reported in 141 (8\%) of 1762 children receiving an INH dosage of 10 $\mathrm{mg} / \mathrm{kg}$ and 139 (9.8\%) of 1406 children receiving dosages of $10-20 \mathrm{mg} / \mathrm{kg}$.

However support is lent to the risk of increased concentrations of INH, or its metabolites, by the finding that, as in adults, children who are phenotypically slow acetylators of INH were more likely to experience a rise in transaminase values above normal. ${ }^{170}$ In the study of Martinez-Roig et al. all children presenting with clinical signs and raised enzyme values were phenotypically slow INH acetylators. ${ }^{178}$ The importance of INH dosage in precipitating severe hepatotoxicity also receives support from adult studies. ${ }^{197}$ In contrast to INH, the dosage of RMP does not appear to be a critical factor in precipitating hepatotoxicity,93,99 although 0'Brien et al. found that RMP dosage became a significant factor in hepatotoxic reactions indicated by AST values above $100 \mathrm{U} / \mathrm{L}$ or increased serum bilirubin. ${ }^{171}$ Several paediatric studies of groups of similar children receiving INH, both with and without RMP, suggest that merely adding RMP to the regimen was sufficient to precipitate severe hepatotoxicity. ${ }^{102,166-169,196}$

PZA is an acknowledged hepatotoxic agent but few publications have addressed its potential to cause ADIH in children; a single case report suggested that RMP and PZA combined might have contributed to serious $\mathrm{ADIH}$ in a 10 year old child. ${ }^{81}$ Two studies of the combination of INH, RMP and PZA for chemotherapy ${ }^{78,79}$ found no evidence that PZA constituted an hepatotoxic risk, but a retrospective study found the use of PZA associated with AST or ALT values $>$ X5 the upper limit of normal, but only 8 of 90 children received PZA and several of these children had more severe disease ${ }^{80}$

In considering the role of PZA it is also of interest that PZA was not used in studies reporting particularly high incidences of jaundice during the treatment of TB, although it was used in several studies using similarly high dosages of INH and RMP during which jaundice was unusual or did not occur.16,96, 104,105 It should also be noted that several literature reviews concluded that the risk of hepatotoxicity associate with PZA dosages of 30-40 $\mathrm{mg} / \mathrm{kg}$ in adults was not excessive. ${ }^{198-200}$

Comparisons of the results of this review with those of adults receiving similar regimens for tuberculosis disease treatment are difficult. ADIH associated with treatment of disease is more complex and few studies include both adults and children allowing a direct comparison of the same regimens in the same populations. Amongst groups of children treated for tuberculosis, other than TBM, the incidence of increased transaminase values is approximately $10 \%$ and similar to that amongst children receiving chemoprophylaxis; the percentage of children becoming jaundiced is, however, considerable higher, overall $1.2 \%$ compared to $0.01 \%$ amongst those receiving chemoprophylaxis and it should be emphasized that this figure is strongly influenced by very high rates of jaundice in a small number of studies, in nearly all of which cases the children were receiving INH dosages of $20 \mathrm{mg} / \mathrm{kg}$ or $10-20 \mathrm{mg} / \mathrm{kg}$.

Table 4 summarizes selected studies reporting adult pulmonary tuberculosis patients receiving INH and RMP with documented increases in serum transaminase values above the upper limit of normal after the start of treatment; the mean percentage $(22 \%)$ is approximately twice that in children suggesting a greater propensity for $\mathrm{ADIH}$ in adults. While it might be more valid to consider those children with transaminase values that were $>\mathrm{X} 2$ or $>\mathrm{X} 3$ or $>\mathrm{X} 5$ normal this information is seldom provided.

In the meta-analysis of Steele et al. 6155 adult patients were evaluated in 19 studies and 168 (2.73\%) diagnosed with clinical hepatitis. ${ }^{204}$ In this present review, excluding chil- 
dren with tuberculous meningitis, and accepting the occurrence of jaundice as evidence of severe $\mathrm{ADIH}, 70 / 8984$ (0.78\%) children developed severe clinical hepatitis and an additional $31(0.35 \%)$ developed symptoms indicative of ADIH. These figures are, again, strongly influenced by the occurrence of jaundice amongst the 453 children receiving INH and RMP only, with INH in a dosage of $10-20 \mathrm{mg} / \mathrm{kg}$. Omitting these groups, only $18(0.36 \%)$ cases of jaundice occurred amongst 8494 children treated for tuberculosis disease.

A tentative conclusion of this review might thus be that INH dosages of $5-15 \mathrm{mg} / \mathrm{kg}$ alone or in the company of other drugs do not constitute and undue risk for the development of ADIH in children.

As regards RMP it seems likely that RMP itself carries a relatively small risk of $\mathrm{ADIH}$, but, for reasons not fully understood, can precipitate ADIH particularly with INH dosages of $>15 \mathrm{mg} / \mathrm{kg}$. The dosage of RMP does not appear critical in this interaction. From what is known of the serum concentrations of RMP achieved in children it would appear that dosages of $10-20 \mathrm{mg} / \mathrm{kg}$ can be safely recommended for children up to the age of 13 years with a proportionately lower dosage with increments in weight. ${ }^{205}$ Despite recent concern about the hepatotoxicity of PZA in adults, both in chemoprophylaxis and in disease treatment, this review produced little evidence that PZA makes a major contribution to ADIH in multidrug regimens in children. In only one study was there an indication that PZA made a significant contribution to ADIH, and this depended upon the influence of eight children receiving PZA. ${ }^{80}$ In several studies the highest incidences of ADIH occurred amongst children not receiving $\mathrm{PZA}$. The dosage of PZA used in the studies reviewed varied from $25 \mathrm{mg} / \mathrm{kg}$ to 40 $\mathrm{mg} / \mathrm{kg}$ and there was no suggestion that the dosage of PZA made any contribution to the development of ADIH. Thus it is likely that a PZA dosage of $30-40 \mathrm{mg} / \mathrm{kg}$, with appropriate adjustments for age, can be recommended for use in children.

There is little information regarding the interaction of other infectious diseases in particular HIV-infection and ADIH in children. Evidence from adults is conflicting at present and while some studies suggest that HIVinfected individuals may be exposed to a reduced risk of $\mathrm{ADIH}{ }^{86}$ other studies found that the risk was unaltered amongst those who are HIV-infected 206,207 and yet other studies found HIV infection an independent risk factor for $\mathrm{ADIH} .88$ In a recent randomized controlled study of INH prophylaxis in 263 HIV-infected children serum ALT was raised in $2(0.02 \%)$ of 131 children receiving placebo, but none of the 132 receiving INH. ${ }^{208}$ Particularly in developing countries the various forms of infectious hepatitis play a role in $\mathrm{ADIH}$, both in possibly precipitating toxicity and in confusing the diagnosis of ADIH. Amongst adults and children there is ample evidence that a significant proportion of patients with ADIH may have underlying infectious hepatitis ${ }^{87,89-91}$ Amongst 85 Indian patients, mainly adults, presenting with acute liver failure associated with ADIH 15 (17.6\%) had associated hepatitis virus infection. ${ }^{209}$ In children this combination may be associated with a high mortality and it is thus a potentially serious problem. 98

\section{Limitations}

The papers reviewed stretch back over more than 50 years and their scientific quality therefore varies considerably. The terms hepatotoxicity, hepatitis, liver damage and liver injury are used interchangeably and each term could be debated. In many instances the purpose of the study was the evaluation of chemoprophylaxis or treatment efficacy; in only a minority was the purpose the documentation of hepatotoxicity. Much data relating to ADIH is thus fragmentary; LFT were seldom performed routinely in early studies and cases of hepatotoxicity might well have been missed or not reported. None the less the occurrence of an outstanding event such as jaundice, or indeed death, as result of liver failure in a child, is most unlikely to have been missed by astute clinicians. Criteria for suspending treatment also vary and where some studies follow the recommendations of the ATS in this respect, other clinicians, for example, suspended treatment following a two-fold rise in transaminase values, irrespective of the presence of symptoms. Despite these reservations a substantial body of data has been assembled that may be valuable when assessing the risks of ADIH attached to different dosages of INH, RMP and PZA to be used in children.

In conclusion this review confirms that $\mathrm{ADIH}$ does occur in children and that vigilance is always necessary if the tragedy of acute liver failure is to be prevented in children. None the less the incidence of ADIH in children is considerably lower than in adults and the newly recommended dosages of INH, RMP and PZA for children do not appear to constitute an added risk factor for $\mathrm{ADIH}$.

\section{References}

1. Graham SM. Treatment of paediatric TB: revised WHO guidelines. Paediatr Respir Rev 2011;12:22-6.

2. Saukkonen JJ, Cohn DL, Jasmer RM, et al. An Official ATS statement: Hepatotoxicity of antituberculosis thera- py. Am J Respir Crit Care Med 2006;174:935-52.

3. Council for International Organizations of Medical Sciences. Criteria of druginduced liver disorders. Report of an International Concensus Meeting. J Hepatol 1990;11:272-6.

4. World Health Organization.International Monitoring of Adverse Reactions to Drugs: Adverse reaction Terminology. Uppsala: WHO Collaborating Centre for International Drug Monitoring. 1992.

5. Galen RS, Weiner D, Hartman SA. Functional hepatic impairment in pulmonary tuberculosis. Dis Chest 1950;17:524-31.

6. Seife M, Kessler BJ, Hoffman J, Lisa JR. A clinical, functional and needle biopsy study of the liver in pulmonary tuberculosis. Am Rev Tuberc 1951;63:202-9.

7. Buckingham WB, Turner GC, Knapp WB, et al. Liver biopsy in a tuberculosis hospital. Dis Chest 1956;29:675-83.

8. Korn RJ, Kellow WF, Heller P, et al. Hepatic involvement in extrapulmonary tuberculosis. Am J Med 1959;27:60-71.

9. Choremis C, Vlachos J, AnastasseaVlachou C, Matsaniotis N. Needle biopsy of the liver in various forms of childhood tuberculosis.J Pediatr 1963;62:203-7.

10. Bolletti M, Sparta D. Le foie dans la tuberculose de l'enfance (recherches histologiques sur le matériel de ponctiobiopsie). Pédiatrie 1959;14:269-78

11. Praharaj KC, Praharaj SC, Nanda BK, Rao PG. Hepatic involvement in childhood tuberculosis. Indian Pediatr 1979;16:497502.

12. Dieckhoff von J. Funktionelle Untersuchengen zur frage einer Leberschädigung durch Isonikotinsäuerehydrazid (INH) im Kindesalter. Munchen Med Wchskr 1957;99:1408-11.

13. Simon K. Rifampicin behandlung der Tuberkulose im Kindesalter. Med Klin 1975;70:1095-7.

14. Litt IF, Cohen MI, McNamara H. Isoniazid hepatitis in adolescents. J Pediatr 1976;89:133-5.

15. Dickinson DS, Bailey WC, Hirschowitz BI, et al. Risk factors for isoniazid (INH)induced liver dysfunction $\mathrm{J}$ Clin Gastroenterol 1981;3:271-9.

16. Donald PR, Schoeman JF, van Zyl LE, et al. Intensive short course chemotherapy in the management of tuberculous meningitis. Int J Tuberc Lung Dis 1998;2:704-11.

17. Robitzek EH, Selikoff IJ. Hydrazine derivatives of isonicotinic acid (Rimifon, Marsalid) in the treatment of active progressive caseous-pneumonic tuberculosis. Am Rev Tuberc 1952;65:402-28.

18. Domagk G, Klee P. Die Behandlung der 
Tuberkulose mit Neoteben (Isonikotinsaurehydrazid). Deutsh Med Wschr 1952;77:578-81.

19. Blattner RJ. Isoniazid prophylaxis in tuberculin reactors. J Pediatr 1968;72: 131-3.

20. Garibaldi RA, Drusin RE, Ferebee SH, Gregg MB. Isoniazid-associated hepatitis. Am Rev Respir Dis 1972;106:357-65.

21. Comstock GW. Prevention of tuberculosis among tuberculin reactors: maximizing benefits, minimizing risks. JAMA 1985;256:2729-30.

22. Israel HL, Gottleib JE, Maddrey WC. Perspective: preventive isoniazid therapy and the liver. Chest 1992;101:1298-301.

23. Scharer L, Smith JP. Serum transaminase elevations and other hepatic abnormalities in patients receiving isoniazid. Ann Intern Med 1969;71:1113-20.

24. Lees AW, Asgher B, Hashem MA, Sinha BN. Jaundice after rifampicin. Br J Chest 1970;64:90-5.

25. Black M. Isoniazid and the liver. Am Rev Respir Dis 1974;110:1-3.

26. Riska N. Hepatitis cases in isoniazid treated groups and in a control group. Bull Internat Union Tuberc 1976;51:203-8.

27. Mitchell JR, Zimmerman HJ, Ishak KG, et al. Isoniazid liver injury: clinical spectrum, pathology, and probable pathogenesis. Ann Intern Med 1976;84:181-92.

28. Rubin B, Hassert GL, Thomas BGH, Burke JC. Pharmacology of isonicotinic acid hydrazide (Nydrazid). Am Rev Tuberc 1952;65:392-401.

29. Camba R. Su un caso di avelenamento mortale da isonicotilidrazide. Boll Soc Ital Biol Sper 1953;29:385-6.

30. Grimminger A. Toxische Wirkungen des Isonikotinsäurehydrazids (Suicid mit Neoteben). Beitr Klin Tuberk 1953;110:387-93.

31. Randolph H, Joseph S. Toxic hepatitis with jaunidice occurring in a patient treated with isoniazid. JAMA 1953;152:3840.

32. Haber E, Osborne RK. Icterus and febrile eactions in response to isonicotinic acid hydrazine. Report of two cases and review of the literature. $\mathrm{N}$ Eng $\mathrm{J}$ Med 1959;260:417-20.

33. Cohen R, Kalser MH, Thomson RV, Gables C. Fatal hepatic necrosis secondary to isoniazid therapy. JAMA 1961;176:877-9.

34. Perera RD, Cowley RG. Hepatocellular damage due to INH. Transactions of the 28th VA Armed Forces Pulmonary Disease Research Conference. Washington DC: 1969; pp. 12-3.

35. Baron DN, Bell JL. Serum enzyme changes in patients receiving antituberculosis therapy with rifampicin or $\mathrm{p}$ aminosalicylic acid, plus isoniazid and streptomycin. Tubercle 1964;55:115-20.

36. Berté SJ, Dimase JD, Christianson CS. Isoniazid, para-aminosalicylic acid, and streptomycin intolerance in 1,744 patients. Am Rev Respir Dis 1964;90:598606.

37. Ferebee SH. Controlled chemoprophylaxis trials in tuberculosis. A general review. Adv Tuberc Research 1970;17:28-106.

38. Possuelo LG, Castelan JA, de Brito TC, et al. Association of $\mathrm{N}$-acetyltransferase 2 profile and anti-TBdrug-induced hepatotoxicity in patients from Southern Brazil. Eur J Clin Pharmacol 2008;64:673-81.

39. Cho HJ, Hoh WJ, Ryu YJ, et al. Genetic polymorphisms of NAT2 and CYP2E1 associated with antituberculosis druginduced hepatotoxicity in Korean patients with pulmonary tuberculosis. Tuberculosis 2007;87:551-6.

40. Higuchi N, Tahara N, Yanagihara K, et al. NAT2 $* 6$ A, a haplotype of the $\mathrm{N}$-acetyltransferase 2 gene, is an important biomarker for risk of anti-tuberculosis druginduced hepatotoxicity in Japanese patients with tuberculosis. World $\mathbf{J}$ Gastroenterol 2007;13:6003-8.

41. Huang Y-S, Chern H-D, Su WJ, et al. Polymorphism of the $\mathrm{N}$-acetyltransferase 2 gene as a susceptibility risk factor for antitubercuolosis drug-induced hepatitis. Hepatology 2002;35:883-9.

42. Musch E, Eichelbaum M, Wang JK, et al. Die Häufigkeit hepatotoxischer Kombinationstherapie Nebenwirkungen der tuberkulostatischen (INH, RMP, EMB) in Abhängigkeit vom Aceyliererphänotyp. Klin Wchschr 1982;60:513-9.

43. Gurumurthy P, Krishnammurthy MS, Nazareth 0 , et al. Lack of relationship between hepatic toxicity and acetylator phenotype in three thousand South Indian patients during treatment with isoniazid for tuberculosis. Am Rev Respir Dis 1984;129:58-61.

44. Cocchi C. Cortisone and corticotrophin in the treatment of tuberculosis in infancy and childhood. Am Rev Tuberc 1956;74:209-16.

45. Debré R. Systematic treatment of primary tuberculosis. Am Rev Tuberc 1956;74:1916.

46. Lincoln EM, Lythcott GI. Tuberculous meningitis developing in the course of isoniazid therapy. Am Rev Tuberc 1956;73:940-3.

47. Miller FJW, Seal RME, Taylor MD. Tuberculosis in children. J \& A Churchill. London: 1963; pp. 163-87.

48. Comstock GW. Isoniazid prophylaxis in an undeveloped area. Am Rev Respir Dis 1962;82:810-22.

49. Egsmose T, Ang'awa JOW, Poti SJ. The use of isoniazid among household con- tacts of open cases of pulmonary tuberculosis. Bull Wld Hlth Org 1965;33:419-33.

50. Curry FJ. Prophylactic effect of isoniazid in young tuberculin reactors.N Eng $\mathrm{J}$ Med 1967;277:562-7.

51. Chevrel B, Rifampicine et foie. Presse Med 1971;79:1911-2.

52. Hughes F-C, Marche C, Marche J. Effets hépato-biliares de l'association rifampicine-isoniazide. I -Etude histologique chez le rat. Thérapie 1969;24: 899-906.

53. Lees AW, Allan GW, Smith J, et al. Toxicity from rifampicin plus isoniazid and rifampicin plus ethambutol therapy. Tubercle 1971;52:182-90.

54. Lees AW, Allan GW, Smith J, et al. Rifampin plus isoniazid in initial therapy of pulmonary tuberculosis and rifampin and ethambutol in retreatment cases. Chest 1972;61:579-82.

55. Binda G, Domenichini E, Gottardi A, et al. Rifampicin, a general review. Arzneimittel-forschung 1971;21:1907-62.

56. Askgaard D, Wilcke T, Døssing M. Hepatotoxicity caused by the combined action of isoniazid and rifampicin. Thorax 1995;50:213-4.

57. Sarma GR, Immanuel C, Kailasam S, Narayana ASL. Rifampin-induced release of hydrazine from isoniazid. Am Rev Respir Dis 1986;133:1072-5.

58. McDermott W, Ormond L, Muschenheim $\mathrm{C}$, et al. Pyrazinamide-isoniazid in tuberculosis. Am Rev Tuberc 1954;69:319-33.

59. Muschenheim C, Organick A, McCune R, et al. Pyrazinamide-isoniazid in tuberculosis. Am Rev Tuberc Pulmon 1954;72:851-5.

60. Girling DJ. The hepatic toxicity of antituberculosis regimens containing isoniazid, rifampicin and pyrazinamide. Tubercle 1978;59:13-32.

61. Hong Kong Chest Service/British Medical Research Council. Controlled trial of 2, 4, and 6 months of pyrazinamide in 6month, three-times-weekly regimens for smear-positive pulmonary tuberculosis, including an assessment of a combined preparation of isoniazid, rifampin, and pyrazinamide. Am Rev Respir Dis 1991; 143:700-6.

62. Graczyk J, 0'Brien RJ, Bek E, et al. Assessment of rifampin-containing regimens for tuberculosis preventive therapy: preliminary results of a pilot study in Poland. Am Rev Respir Dis 1991;143:A119.

63. Gordin F, Chaisson RE, Matts JP, et al. Rifampin and pyrazinamide vs isoniazid for prevention of tuberculosis in HIVinfected persons. JAMA 2000;283:1445-50.

64. Halsey NA, Coberly JS, Desmoreaux J, et al. Randomised trial of isoniazid versus 
rifampicin and pyrazinamide for prevention of tuberculosis in HIV-1 infection. Lancet 1998;351:786-92.

65. Mwinga A, Hosp M Godfrey-Fausset P, et al. Twice weekly tuberculosis preventive therapy in HIV infection in Zambia. AIDS 1998;12:2447-57.

66. American Thoracic Society/Centers for Disease Control and Prevention.Targeted tuberculin testing and treatment of tuberculosis infection. Am J Respir Crit Care Med 2000;161:S221-47.

67. Hofmann J, Osborn M, Hoffman B. Adverse events associated with the use of pyrazinamide and rifampin for the treatment of latent tuberculosis infection. Clin Infect Dis 2001;33:1146.

68. King MD, Abdulrahman S, Oladele A, et al. A randomized trial of 2 months of rifampin and pyrazinamide vs 6 months of isoniazid for the treatment of latent tuberculosis infection in HIV negative patients. Clin Infect Dis 2001;33:1146.

69. Cook PP, McNeil EL. Comparison of a two month regimen of pyrazinamide and rifampin with a six month regimen of isoniazid for treatment of patients with latent tuberculous infection. Clin Infect Dis 2001;33:1147.

70. McNeil L, Allen M, Estrada C, Cook P. Pyrazinamide and rifampin vs isoniazid for the treatment of latent tuberculosis: improved completion rates but more hepatotoxicity. Chest 2003;123:102-26.

71. Stout JE, Engemann JJ, Cheng AC, et al. Safety of 2 months of rifampin and pyrazinamide for treatment of latent tuberculosis. Am J Respir Crit Care Med 2003;167:824-7.

72. Lee AM, Mennone JZ, Jones RC, Paul WS. Risk factors for hepatotoxicity associated with rifampin and pyrazinamide for the treatment of latent tuberculosis infection: experience from three public health tuberculosis clinics. Int J Tuberc Lung Dis 2002:6:995-1000.

73. Kandula N, Dworkin M, Carrol MR, Lauderdale DS. Tuberculosis prevention in Mexican immigrants. Limitations of short-course therapy. Am J Prev Med 2004;26:163-6.

74. McElroy PD, Ijaz K, Lambert LA, et al. National survey to measure rates of liver injury, hospitalization, and death associated with rifampin and pyrazinamide for latent tuberculosis infection. Clin Infect Dis 2005;41:1125-33.

75. Chang $\mathrm{KC}$, Leung $\mathrm{CC}$, Yew WW, et al. Hepatotoxicity of pyrazinamide. Am J Respir Crit Care Med 2008;177:1391-6.

76. Bock NN, Rogers T,Tapia JR, et al. Acceptability of short-course rifampin and pyrazinamide treatment of latent tuberculosis infection among jail inmates. Chest
2001;119:833-7.

77. Magdorf K, Arrizi-Rusche AF, Geiter LJ, et al. Compliance und Toleranzer neuer antituberkulotischer

KurzzeitChemopräventions regime im Kindesalter-eine Pilotstudie. Pneumologie 1994;48:761-4.

78. Le Bourgeois M, de Blic J, Paupe J, Scheinmann P. Good tolerance of pyrazinamide in children with pulmonary tuberculosis. Arch Dis Child 1989;64:177-8.

79. Sánchez-Albisua I, Vidal ML, Joya-Verde $\mathrm{G}$, et al. Tolerance of pyrazinamide in short course chemotherapy for pulmonary tuberculosis in children. Pediatr Infect Dis J 1997;16:760-3.

80. Ohkawa K, Hashiguchi M, Ohno K, et al. Risk factors for antituberculous chemotherapy induced hepatotoxicity in Japanese pediatric patients. Clin Pharmacol Ther 2002;72:220-6.

81. van Aalderen WMC, Knoester H, Knol K. Fulminant hepatitis during treatment with rifampicin, pyrazinamid and ethambutol. Eur J Pediatr 1987;146;290-1.

82. Wu J-C, Lee S-D,Yeh PF, et al. Isoniazidrifampin-induced hepatitis in hepatitis $\mathrm{B}$ carriers. Gastroenterology 1990;98:502-4.

83. Hwang S-J, Wu J-C, Lee C-N, et al. A prospective clinical study of isoniazidrifampicin-pyrazinamide-induced liver injury in an area endemic for hepatitis B. J Gastroenterol Hepatol 1997;12:87-91.

84. Lee BH, Koh W-J, Choi SC, et al. Inactive hepatitis B surface antigen carrier state and hepatotoxicity during antituberculosis chemotherapy. Chest 2005;127:130411.

85. McGlynn KA, Lustbader ED, Sharrar RG, et al. Isonaizid prophylaxis in hepatitis B carriers. Am Rev Respir Dis 1986;134:6668.

86. Hoffmann CJ, Charalambous SA, Thio CL, et al. Hepatotoxicity in an African antiretroviral therapy cohort: the effect of tuberculosis and hepatitis B. AIDS 2007;21:1301-8.

87. Türktas H, Ünsal M, Tülek N, Örük 0 . Hepatotoxicity of antituberculosis therapy (rifampicin, isoniazid and pyrazinamide) or viral hepatitis. Tuberc Lung Dis 1994;75:58-60.

88. Ungo JR, Jones D, Ashkin D, et al. Antituberculosis drug-induced hepatotoxicity. The role of hepatitis $\mathrm{C}$ virus and human immunodeficiency virus. Am J Respir Crit Care 1998;157:1871-6.

89. Sarda P, Sharma SK, Mohan A, et al. Role of acute viral hepatitis as a confounding factor in antituberculosis treatment induced hepatotoxicity. Indian J Med Res 2009;129:64-7.

90. Sharma SK, Singla R, Sreenivas V, et al. Acute viral hepatitis as a confounding fac- tor in patients with antituberculosis treatment induced hepatotoxicity. Indian J Med Res 2009;130:200-1.

91. Singla R, Sharma SK, Mohan A, et al. Evaluation of risk factors for antituberculosis treatment induced hepatotoxicity. Indian J Med Res 2010;132:81-6.

92. Sweetnam WP, Murphy EF. Isonicotinic acid hydrazide in the treatment of tuberculous meningitis in children. Lancet 1952;2:160-1.

93. Dieu M J-C, Adenis-Lamarre F, Bitar M, Dabagh M. La rifampicine dans le traitement des formes ganglio-pulmonaires de la tuberculose initiale du nourisson et de l'enfant. Rev Tuberc Pneumol 1970;34: $320-31$.

94. Kramer R, Simon K. Eigene Erfahrungen mit Rifampicin. Prax Pneumol 1971;25: 610-4.

95. Stein MT, Liang D. Clinical hepatotoxicity of isoniazid in children. Pediatrics 1979;64:499-505.

96. Donald PR, Schoeman JF, O'Kennedy A. Hepatic toxicity during chemotherapy for severe tuberculous meningitis. Am J Dis Child 1987;141:741-3.

97. Ramachandran P, Kripasankar AS, Duraipandian M. Short course chemotherapy for pulmonary tuberculosis in children. Indian J Tuberc 1998;45:83-7.

98. Kumar A, Misra PK, Mehotra R, et al. Hepatotoxicity of rifampin and isoniazid. Is it all drug-induced? Am Rev Respir Dis 1991;143:1350-2.

99. Dieu M J-C. Role de l'Isoniazide dans l'hepatotocicite de l'association INHrifampicine dans la tuberculose de l'enfant. J Med Lyon 1972;53:1323-7.

100. Burghard G, Peter M0, Girondel P. Utilasation de la rifampicine dans le traitment de la tuberculose chez l'enfant. J Med Strasbourg 1973;4:665-71.

101. Ramachandran P. Chemotherapy of tuberculous meningitis with isoniazid plus rifampicin - interim findings in a trial in children. Ind J Tuberc 1980;27:54-62.

102. Rugamini PS, Mehta S. Hepatotoxicity of isoniazid and rifampin in children. Indian Pediatr 1984;21:119-26.

103. Tsagaropoulou-Stinga H, MatakiEmmanouilidou T, Karida-Kavalioti S, Manios S. Hepatotoxic reactions in children with severe tuberculosis treated with isoniazid-rifampin. Pediatr Infect Dis J 1985;4:270-3.

104. Donald PR, Gent WLG, Siefart HI, et al. Cerebrospinal fluid isoniazid concentrations in children with tuberculous meningitis: the influence of dosage and acetylation status. Pediatrics 1992;89:247-50.

105. Gismão Filho FAR, Marques-Dias MJ, Marques HH de S, Ramos SRT de S. Tuberculose do system nervosa central 
em criancas. Arq Neuropsiquiatr 2001;59:77-82.

106. Brügger Von $H$. Leber schäden durch Isonikotinylhydrazin (INH) bei kleinkindern. Tuberkuloseartz 1956;10:339-46.

107. Davies D, Glowinski JJ. Jaundice due to isoniazid. Tubercle 1961;42:504-6.

108. Bonnet RJH, Pages P, Dumas R, Greze J. Hépatite médicamenteuse ai cours d'un traitment associant isoniazide et rifampicine. Ann Pédiatr 1972;19:307-11.

109. Rudoy R, Stuemky J, Poley JR. Isoniazid administration and liver injury. Am J Dis Child 1973;125:733-6.

110. Merlin D, Vest M, Just M, Bianchi L. Ein Fall Isoniazid-Hepatitis beim Kind. Schweiz med Wschr 1974;104:1326-30.

111. Casteels-Van Daele M, Igodt-Ameye L, et al. Hepatotoxicity of rifampicin and isoniazid in children. J Pediatr 1975;86:739-41.

112. Allué X, Sanjurjo P, Fidalgo I, Bilbao F. Hepatic toxicity of antituberculous drugs in children. Helv Paediatr Acta 1976;31:381-7.

113. Brasfield DM, Goodloe TB, Tiller RE. Isoniazid hepatotoxicity in childhood. Pediatrics 1976;58:291.

114. Vanderhoof JA, Ament ME. Fatal hepatic necrosis due to isoniazid chemoprophylaxis in a 15-year old girl. J Pediatr 1976;88:867-8.

115. Walker SH, Park-Hah JO. Possible isoniazid induced hepatotoxicity in a two-yearold child. J Pediatr 1977;91:344-5.

116. Chapoy P, Ferraci JP, Mattei JF, et al. Hepatopathie grave induite par chimiothérapie anti-tuberculeuse chez l'enfant. Pediatrie 1978;33:637-45.

117. Gutman L. More adverse reactions to rifampicin. J Antimicrob Chemother 1978;4:283-94.

118. Bistritizer T, Barzilay Z, Jonas A. Isoniazid-rifampin-induced fulminant liver disease in an infant. J Pediatr 1980;97:480-2.

119. Bonora G, De La Pierre L, Perletti L. Epatotossicitatà dell'associzione rifampicina-isoniazide nel bambino. Min Pediatr 1981;33:835-6.

120. Urzainqui SU, Aliberch RMM, Pau JS, Bernaldo AMB. Hidracida-rifampicina: hepatotoxicidad en el ni $\square$ o. An Esp Pediatr 1981;15:401-3.

121. Palusci VJ, O'Hare D, Lawrence RM. Hepatotoxicity and transaminase measurement during isoniazid chemoprophylaxis in children.Pediatr Infect Dis J 1995;14:144-8.

122. Gal AA, Klatt EC. Fatal isoniazid hepatitis in a child. Pediatr Infect Dis 1986;5:490-1.

123. Moulding TS, Redeker AG, Kanel GC. Twenty isoniazid associated deaths in one state. Am Rev Respir Dis
1989;140:700-5.

124. Hasagawa T, Reyes J, Nour B, et al. Successful liver transplantation for isoniazid-induced liver failure - a case report. Transplantation 1994; 57:1274-7.

125. Meyers BR, Halpern M, Sheiner P, et al. Acute hepatic failure in seven patients after prophylaxis and therapy with antituberculous agents. Transplantation 1994;58:372-7.

126. Berkowitz FE, Henderson SL, Fajman N, et al. Acute liver failure caused by isoniazid in a child receiving carbamazepine. Int J Tuberc Lung Dis 1998;2:603-6.

127. Cillo U, Bassanello M, Vitale A, et al. Isoniazid-related fulminant hepatic failure in a child: assessment of the native liver's early regeneration after auxillary partial orthoptic liver transplantation. Transpl Int 2005;17:713-6.

128. Lobato MN, Jereb JJ, Starke JR. Unintended consequences: mandatory tuberculin skin testing and severe isoniazid hepatotoxicity. Pediatrics 2008;121:e1732-3.

129. Wu SS, Chao CS, Vargas JH, et al. Isoniazid related hepatic failure in children: a survey of liver transplantation centers. Transplantation 2007;84:173-9.

130. Snider DE, Caras GJ. Isoniazid-associated hepatitis deaths: a review of available information. Am Rev Respir Dis 1992;145:494-7.

131. Mount FW, Ferebee SH. Preventive effects of isoniazid in the treatment of primary tuberculosis in children. New Eng $\mathrm{J}$ Med 1961;265:713-21.

132. Litt I F, Cohen M I, McNamara H. Isoniazid hepatitis in adolescents. J Pediatr 1976;89:133-5.

133. Spyridis P, Sinaniotis C, Papadea I, et al. Isoniazid liver injury during chemoprophylaxis. Arch Dis Child 1979;54:65-7.

134. Tortajada C, Martinez-Lacasa J, Sánchez F, et al. Is the combination of pyrazinamide plus rifampicin safe for treating latent tuberculosis infection in persons not infected by the human immunodeficiency virus? Int $\mathrm{J}$ Tuberc Lung Dis 2005;9:276-81.

135. Ito K, Hoshino H, Nakazono T, et al. Liver damage in treatment of latent tuberculous infection by isoniazid. Kekkaku 2006;81:651-60.

136. Marais BJ, van Zyl S, Schaaf HS, et al. Adherence to isoniazid preventive chemotherapy : a prospective community based study. Arch Dis Child 2006;91:7625.

137. Beaudry PH, Brickman HF, Wise MB. Liver enzyme disturbances during isoniazid chemoprophylaxis in children Am Rev Respir Dis 1974;110:581-4.

138. Nakajo MM, Rao M, Steiner P. Incidence of hepatotoxicity in children receiving isoniazid chemoprophylaxis. Pediatr Infect Dis J 1989;8:649-50.

139. Spyridis NP, Spyridis PG, Gelesme A, et al. The effectiveness of a 9-month regimen of isoniazid alone versus 3- and 4-month regimens of isoniazid and rifampin for treatment of latent tuberculosis infection in children: results of an 11-year ramdomized study. Clin Infect Dis 2007;45;715-22.

140. Kopanoff DE, Snider DE, Caras GJ. Isoniazid-related hepatitis. Am Rev Respir Dis 1978;117:991-1001.

141. Hsu K-HK, Isoniazid in the prevention and treatment of tuberculosis. JAMA 1974;229:528-33.

142. Rapp RS, Campbell RW, Howell JC, Kendig EL. Isoniazid hepatotoxicity in children. Am Rev Respir Dis 1978;118;794-6.

143. Byrd RB, Horn BR, Solomon DA, Griggs GA. Toxic effects of isoniazid in tuberculosis chemoprophylaxis. Role of biochemical monitoring in 1,000 patients. JAMA 1979;241:1239-41.

144. Dash LA, Comstock GW, Flynn JPG. Isoniazid preventive therapy. Retrospect and prospect. Am Rev Respir Dis 1980;121:1039-44.

145. Nolan CM, Goldberg SV, Buskin SE. Hepatotoxicity associated with isoniazid preventive therapy. JAMA 1999;281:101418.

146. LoBue PA, Moser KS. Use of isoniazid for latent tuberculosis infection in a public health clinic. Am J Respir Crit Care Med 2003;168:443-7.

147. Villarino ME, Ridzon R, Weismuller PC, et al. Rifampin preventive therapy for tuberculosis infection: experience with 157 adolescents. Am J Respir Crit Care Med 1997;155:1735-8.

148. Lardizabal A, Passannante M, Kojakali F, et al. Enhancement of treatment completion for latent tuberculosis infection with 4 months of rifampin. Chest 2006;130:1712-7.

149. Hong Kong Chest Service, Tuberculosis Research Centre, Madras, British Medical Research Council. A double-blind placebocontrolled clinical trial of three antituberculosis chemoprophylaxis regimens in patients with silicosis in Hong Kong. Am Rev Respir Dis 1992;145:36-41.

150. Polesky A, Farber H, Gottlieb D, et al. Rifampin preventive therapy for tuberculosis in Boston's homeless. Am J Respir Crit Care Med 1996;154:1473-7.

151. Menzies D, Dion M-J, Rabinovitch B, et al. Treatment completion and costs of a randomized trial of rifampin versus isoniazid for 9 months. Am J Respir Crit Care Med 2004;170:445-9.

152. Menzies D, Long R, Trajman A, et al. Adverse events with 4 months of rifampin 
therapy or 9 months of isoniazid therapy for latent tuberculosis infection. Ann Intern Med 2008;149:689-97.

153. Wales JM, Buchan AR, Cookson JB, et al. Tuberculosis in a primary school: the Uppingham outbreak. $\mathrm{Br}$ Med J 1985;291:1039-40.

154. Ormerod LP. Reduced incidence of tuberculosis by prophylactic chemotherapy in subjects showing strong reactions to tuberculin testing. Arch Dis Child 1987;62:1005-8.

155. Ormerod LP. Rifampicin and isoniazid prophylactic chemotherapy for tuberculosis. Arch Dis Child 1998;78:169-71.

156. Rahaju NN, Rahaju SS, Sutejo IB. Rifampicin in combination with isoniazid in the treatment of childhood tuberculosis. Paediatr Indones 1976;16:544-53.

157. Quevedo SI, Bravo GR. Quimioterapia abreviada de 6 meses en tuberculosis pulmonary infantile. Rev Chilina Pediatr 1980;51:249-52.

158. Abernathy RA, Dutt AK, Stead WWS, Moers DJ. Short-course chemotherapy for tuberculosis in children. Pediatrics 1983;72:801-6.

159. Jawahar MS, Sivasubramanian S, Vijayan VK, et al. Short course chemotherapy for tuberculous lymphadenitis. Br Med J 1990;301:359-62.

160. Kumar L, Dhand R, Singhi PD, et al. A randomized trial of fully intermittent vs. daily followed by intermittent short course chemotherapy for childhood tuberculosis. Pediatr Infect Dis J 1990;19:8026.

161. Te Water Naude JM, Donald PR, Hussey GD, et al. Twice weekly vs. daily chemotherapy for childhood tuberculosis. Pediatr Infect Dis J 2000;19:405-10.

162. Al-Dossary FS, Ong LT, Correa AG, Starke JR. Treatment of childhood tuberculosis with a six month directly observed regimen of only two weeks of daily therapy. Pediatr Infect Dis J 2002;21:91-7.

163. Hsu K-H. Should primary tuberculosis in children continue to be neglected. J Pediatr 1956;45:501-19.

164. Kuske F-A. Über Nebenerscheinungen bei der INH behandlung der Tuberkulose des kindes. Artzl Wschr 1953;8:765-9.

165. Sifontes JE, De Garau PD, Vicens CN, Acosta R. The treatment of primary tuberculosis in children. Bol Asoc Med Puerto Rico 1955;47:58-63.

166. Gerbeaux J, Hanateau J. Médications récented dans le traitement de la tuberculose primaire. Ann Péditr 1970;17:638-43.

167. Hsu KHK. Thirty years after isoniazid. JAMA 1984; 251:1283-5.

168. Rahajoe NN, Rahajoe N, Boediman I, et al. The treatment of tuberculous meningitis in children with a combination of iso- niazid, rifampicin and streptomycin - a preliminary report. Tubercle 1979;60:24550.

169. Bassetti D, Ciravegna B, Viscoli C. Rifampicin's tolerance in paediatrics. Drugs Exptl Clin Res 1982;8:255-7.

170. Mantero E, Penco G, Marazzi MG, et al. Hepatic toxicity caused by isoniazid (INH) in children affected by tuberculosis: an investigation on the relations with the acetylator phenotype and the isoniazid plasmatic levels. Gio Malat Infect Parasit 1983;25:1385-7.

171. 0'Brien RJ, Long MW, Cross FS. Hepatotoxicity from isoniazid and rifampin among children treated for tuberculosis. Pediatrics 1983;72:491-9.

172. Varadkar BL. Short course chemotherapy for tuberculosis in children. Indian $\mathrm{J}$ Pediatr 1985;52:593-7.

173. Nemir RL, O'Hare D. Tuberculosis in children 10 years of age and younger: three decades of experience during the chemotherapeutic era. Pediatrics 1991;88:236-41.

174. Seth V, Beotra A. Hepatic function in relation to acetylator phenotype in children treated with antitubercular drugs. Indian J Med Res 1989;89:306-9.

175. Reis FJC, Bedran MBM, Moura JAR, et al. Six-month isoniazid-rifampin treatment for pulmonary tuberculosis in children. Am Rev Respir Dis 1990;142:996-9.

176. Linna 0, Uhari M. Hepatotoxicity of rifampicin and isoniazid in children treated for tuberculosis.Eur J Pediatr 1980;134:227-9.

177. Beltran POR, Pelosi, Budani H, et al. The treatment of child tuberculosis with isoniazid $(\mathrm{H})$, rifampicin (R), and pyrazinamide (Z). Bull Int Union Tuberc 1986;61:17.

178. Martinez-Roíg A, Camí J, Llorens-Terol J, et al. Acetylation phenotype and hepatotoxicity in the treatment of tuberculosis in children. Pediatrics 1986;77:912-5.

179. Rhakit A, Khandelwal PG, Mukherjee SK, Dey AK. Intensive short course chemotherapy in pulmonary tuberculosis. Indian Pediatr 1986;53:243-8.

180. Medical Research Council Tuberculosis and Chest Diseases Unit. Management and outcome of chemotherapy for childhood tuberculosis. Arch Dis Child 1989;64:1004-12.

181. Anane T, Cernay J, Bensenouci A, et al. An Algerian experiment: short chemotherapy for tuberculosis. Children in the Tropics 1992;78-82.

182. Tsakalidis D, Pratsidou P, HitoglouMakedou A, et al. Intensive short course chemotherapy for treatment of Greek children with tuberculosis. Pediatr Infect Dis J 1992;11:1036-42.
183. Ormerod LP, Horsfield N. Frequency and type of reactions to antituberculosis drugs: observations in routine treatment Tuberc Lung Dis 1996;77:37-42.

184. Corrigan D, Paton J. Hepatic enzyme abnormalities in children on triple therapy for tuberculosis. Pediatr Pulmonol 1999;27:37-42.

185. Kabra SK, Lodha R, Seth V. Category based treatment of tuberculosis in children. Indian Pediatr 2004;41:927-37.

186. Jacobs RF, Abernathy RS. The treatment of tuberculosis in children. Pediatr Infect Dis 1985;4:513-7.

187. Gendrel D, Nardou M, Mouba JF, et al. Hépatotoxicité de l'association isoniazide-rifampicine chez l'enfant Africain. Arch Fr Pediatr 1989;46:645-8.

188. Starke JR, Taylor-Watts KT. Six-month chemotherapy of intrathoracic tuberculosis in children. Am Rev Respir Dis 1989;139:A314.

189. Toppet M, Malfroot A, Hofman B, et al. Tuberculosis in children: a 13 year follow up of 1714 patients in a Belgian home care centre Eur J Pediatr 1991;150:331-5.

190. Padmini R, Srinivasan S, Nalini P, Mahadevan S. Short course chemotherapy for tuberculosis in children. J Trop Pediatr 1993;39:361-4.

191. Vallejo JG, Ong LT, Starke JR. Clinical features, diagnosis and treatment of tuberculosis in infants. Pediatrics 1995;94:1-7.

192. Parasarathy R, Sarma GR, Janardhanam $\mathrm{B}$, et al. Hepatic toxicity in South Indian patients during treatment of tuberculosis with short-course regimens containing isoniazid, rifampicin and pyrazinamide. Tubercle 1986;67:99-108.

193. Jacobs RF, Sunakorn P, Chotpityayasunonah $\mathrm{T}$, et al. Intensive short course chemotherapy for tuberculous meningitis. Pediatr Infect Dis J 1992;11:194-8.

194. Donald PR, Seifart HI, Parkin DP, van Jaarsveld PP. Hydrazine production in children receiving isoniazid for the treatment of tuberculous meningitis. Ann Pharmacother 1994;28:1340-3.

195. Sunakorn P, Wongsaroj P. Rifampin in treatment of tuberculous meningitis. J Med Ass Thailand 1978;61:93-8.

196. Ramachandran P, Duraipandian M, Nagarajan M, et al. Three chemotherapy studies of tuberculous meningitis in children. Tubercle 1986;67:17-29.

197. Altman C, Biour M, Grange JD. Toxicité hépatique des antituberculeux. Róle de différents medicaments. 199 observations. Presse Med 1993;22:1212-6.

198. Zierski M. Pharmakologie, toxikologie und klinische Anwendung von Pyrazinamid. Prax Pneumol 1981;35: 1075-105.

199. Gumbo T, Siyambalapitiyage CSW, Meek 
C, Leff R. Pharmacokinetics-pharmacodynamics of pyrazinamide in a novel in vitro model of tuberculosis for sterilizing effect: a pardigm for faster assessment of new antituberculosis drugs. Antimicrob Agents Chemother 2009;53:3197-204.

200. Pasipanodya JG, Gumbo T. Clinical and toxicodynamic evidence that high-dose pyrazinamide is not more hepatotoxic than the low doses currently used. Antimicrob Agents Chemother 2010:54:2847-54.

201. Lal S, Singhal SN, Burley DM, Crossley G. Effect of rifampicin and isoniazid on liver function. Br Med J 1972;1:148-50.

202. Grönhagen-Riska C, Hellstrom P-E, Fröseth B. Predisposing factors in hepati- tis induced by isonaizid-rifampin treatment of tuberculosis. Am Rev Respir Dis 1978;118:461-6.

203. Agal S, Baijal R, Pramanik S, et al. Monitoring and management of antituberculosis drug induced hepatotoxicity. J Gastroenterol Hepatol 2005;20:1745-52.

204. Steele MA, Burk RF, DesPrez RM. Toxic hepatitis with isoniazid and rifampin. A meta-analysis. Chest 1991;99:465-71.

205. Donald PR, Martiz JS, Diacon AH. The pharmacokinetics and pharmacodynamics of rifampicin in adults and children in relation to the dosage recommended for children. Tuberculosis 2011; 91: 196-207.

206. Whalen CC, Johnson JL, Okwera A, et al. A trial of three regimens to prevent tuber- culosis in Ugandan adults infected with the human immunodeficiency virus. New Eng J Med 1997;337:801-8.

207. Bucher HC, Griffith L, Guyatt G, et al. Isoniazid prophylaxis for tuberculosis in HIV infection: a meta-analysis of randomized controlled trials. AIDS 1999;13:501-7.

208. Zar HJ, Cotton MF, Strauss S, et al. Effect of isoniazid prophylaxis on mortality and incidence of tuberculosis in children with HIV : randomised controlled trial. Lancet 2007;334:136-42.

209. Kumar R, Shalimar D, Bhatia V, et al. Antituberculosis therapy-induced acute liver failure: magnitude, profile, prognosis, and predictors of outcome. Hepatology 2010; 51: 1665-1674. 